\title{
TIME SUCK: HOW THE FUNDRAISING TREADMILL DIMINISHES EFFECTIVE GOVERNANCE
}

\section{Ciara Torres-Spelliscy*}

I. INTRODUCTION .272

II. THE CURRENT SHORTSIGHTED JURISPRUDENCE ON CANDIDATE

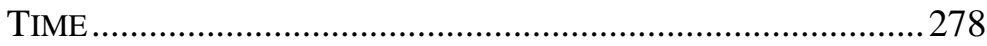

III. FEDERAL ELECTED OFFICIALS ARE WATCHING THEIR DAYS TICK

AWAY AS THEY FUNDRAISE............................................281

A. Pre-Citizens United Fundraising .....................................2282

B. Post-Citizens United Fundraising .....................................228

IV. What Does The Data About FundRaISERS REVEAL?...........291

V. No ONE CAN MULTI-TASK INCLUding ELECTED OfFICIALS .....293

VI. WHAT HAPPENS WHEN INCUMBENT CANDIDATES RUN OUT OF

TIME: POLICY AND FUNDRAISING GET OUTSOURCED ...........296

A. Reforms in Light of the Problem of Dwindling Candidate

Time....

306

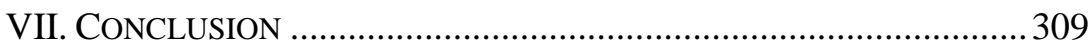

\footnotetext{
*Associate Professor of Law and Leroy Highbaugh Research Chair at Stetson University College of Law and a Fellow at the Brennan Center for Justice at NYU School of Law; AB Harvard; JD Columbia. The author thanks Stetson College of Law for its scholarship grant which allowed this piece to be written, and research assistants Joy Branham, Michael Davids, Kyle Gretel, Ashley Justice, and Felicia Kitzmiller, and law librarians Sally Waters and Kristen Moore for their assistance in helping the author research this piece. The author also thanks the AALS Section on Legislation \& Law of the Political Process for selecting this piece for the "New Voices in Legislation" event.
} 


\section{INTRODUCTION}

There are just not enough hours in the day to get the job done! This is a common experience for many working adults, but this type of "time drought" takes on democratic significance if the individuals experiencing it are democratically elected officials. ${ }^{1}$ Those elected officials may thus lack the ability to effectively represent the constituents who put them in office. ${ }^{2}$ For federal elected officials, one of the causes of the lack of time to craft policy (the job they are elected to do) is caused by political fundraising burdens (the distraction). ${ }^{3}$ As one Congressman put it bluntly: campaign fundraising has become an incredible "time suck" for lawmakers. ${ }^{4}$

This Article will refer to several defined terms: "legislating" means drafting legislation, participating in committee hearings, marking up legislation, amending legislation on the floor, voting on legislation and amendments to legislation, participating in conference committees, and conducting oversight hearings. ${ }^{5}$ Legislating would also include meeting with constituents, traveling home, corresponding with constituents, and offering constituent services. ${ }^{6}$ For Senators, legislative duties would include vetting executive and judicial appointments and ratifying

1 Vincent Blasi, Free Speech and the Widening Gyre of Fund-raising: Why Campaign Spending Limits May Not Violate the First Amendment After All, 94 Colum. L. ReV. 1281, 1312 (1994) (explaining how if candidates did not have to spend all of their time fundraising, they would likely spend at least some of the free time in one's home district, for example); Richard L. Hasen, Three Wrong Progressive Approaches (and One Right One) to Campaign Finance Reform, 8 HARV. L. \& POL'Y REV. 21, 33 (2014) ("The main problem of campaign money on the federal level - aside from the huge time commitment for Members of Congress, who spend so much time dialing for dollars that there is little time for legislative businessis that it skews legislative priorities.").

2 Mark C. Alexander, Let Them Do Their Jobs: The Compelling Government Interest in Protecting the Time of Candidates and Elected Officials, 37 LoY. U. CHI. L. J. 699, 706 (2006).

3 Thomas E. Mann \& Norman J. ORnStein, It's Even Worse Than It Was 67 (2012) ("American elections are awash in money, politicians devote an inordinate amount of their time dialing for dollars, and campaign fund-raising is now considered a normal part of the lobbying process.").

4 Congressman John Sarbanes, Remarks at Scholars Strategy Network: Purchasing Power (June 17, 2016); see also Nick Penniman \& Wendell Potter, Citizens United is Only $15 \%$ of the Political Cash Problem, L.A. TiMES (Mar. 8, 2016), http://www.latimes.com/opini on/op-ed/la-oe-penniman-potter-political-campaign-finance-reform-20160308-tory.html ("As former Rep. Dan Glickman (D-Kan.), who later served as a lobbyist for the motion picture industry, has opined: 'The sad truth is . . there simply isn't enough time in the day to stay competitive in campaign finance and do the actual job of policymaking."').

5 U.S. CONT. art. I, § 1; How Are Laws Made?, U.S. House OF REPRESENTATIVES, (last visited May 10, 2018), https://www.house.gov/the-house-explained/the-legislative-process.

6 Juana Summers, Constituent Services Give Voters Something to Remember, NPR (Oct. 28, 2014), https://www.npr.org/2014/10/28/359615965/constituent-services-give-voters-so mething- to-remember. 
treaties. $^{7}$ Meanwhile, "fundraising" is the act of soliciting funds for a political campaign or political party. ${ }^{8}$ Fundraising would include inperson solicitation of money, and solicitation of money via broadcast, mail, phone or email. "Fundraising" by itself does not fall into any of this Author's definitions of "legislating." And this Author would argue that ideally fundraising should take up a de minimis amount of an elected Member of Congress's time. But while many of the legislative functions outlined in this paragraph are done by legislative staff who work for the Member, strangely fundraising is often not delegated to a staff member, but rather is the responsibility of the Member himself or herself.

Perhaps the clearest evidence that fundraising should not be considered part of a Member's job is the fact that it is literally illegal to do the fundraising in a Congressional office where he or she otherwise works. $^{9}$ The fundraising cubicles set up for Members of Congress in nearby office spaces for dialing for dollars have been called "sweatshops." 10 Or as former Senator Alan Simpson recalled of his time fundraising when he was a Senator, "II felt embarrassed. I thought it was ugly... My staff kept saying, 'You've got to go do it.' You get a Rolodex; you go outside the building for a whole day and dial numbers of jerks you've never heard of in your whole life to get money out of "em."11 Typically, the public does not get to sit in on Congressmen and Congresswomen dialing for dollars, but in 2013 (a non-election year), political reporter Ryan Lizza happened to overhear a freshman Democratic Member of Congress doing call time in a public space for

7 Legislative Process, U.S. SENATE, https://www.senate.gov/legislative/process.htm (last visited May 10, 2018).

8 Fundraising for the Campaign, FED. EleCTION COMM'N, https://www.fec.gov/helpcandidates-and-committees/making-disbursements/fundraising-campaign/ (last visited May 10, 2018); Fundraising for other Candidates, Committees and Organizations, Fed. ElECTION COMM'N, https://www.fec.gov/help-candidates-and-committees/making-disbursements/fund raising-other-candidates-committees/ (last visited May 10, 2018).

9 Bipartisan Campaign Reform Act of 2002, H.R. 2356, § 302, 107th Cong. (2002).

10 Nick Penniman \& Wendell Potter, Nation on the Take: Dialing for Dollars in 'D.C.'s Sweatshops', HuFF. Post (Apr. 27, 2016, 11:01 AM), https://www.huffingtonpost.com/nickpenniman/nation-on-the-take-dialin_b_9787106.html ("Former representative Dennis Cardoza, a California Democrat, compared his party's call center to a sweatshop with thirtyinch-wide cubicles set up for the sole purpose of begging for money."); see also Zach Wamp (R-Tenn.), Refocusing our politics on the issues that matter, THE HILL (Jan. 8, 2018, 2:10 PM), http://thehill.com/blogs/congress-blog/politics/367937-refocusing-our-politics-on-theissues-that-matter ("Every freshman member of Congress packs their bags for Washington already envisioning the more perfect republic they seek to build .... Where freshman members expect to enter storied halls for deliberation, reason, and thought, they find a nonstop call center.").

11 Chris Lee, HBO's John Oliver Exposes the Absurd and Awful Ways Congress Members Raise Money, FoRTUNE (Apr. 4, 2016), http://fortune.com/2016/04/04/john-olivercongress-fundraising-money/ (quoting Senator Simpson). 
two and half hours straight. Mr. Lizza decided to live tweet what he overheard from the Member's side of the conversation. At the end of listening to this multiple hour ordeal, Mr. Lizza concluded: "I now understand the case for public financing of congressional elections." "12

This problem of fundraising-swamped lawmaking is particularly acute post-Citizens United, the 2010 Supreme Court case that allows corporations and unions to spend an unlimited amount on political advertisements in American elections. ${ }^{13}$ Frequently, candidates need to buy expensive television advertisement time and direct mail to communicate with a vast electorate. ${ }^{14}$ Indeed, there is a lucrative cottage industry to "help" candidates spend the money they have raised to communicate with voters. ${ }^{15}$ The election in 2016 was the most expensive federal election to date. ${ }^{16}$ This high price tag in 2016 is attributed to Congressional races, as the spending on the 2016 Presidential race was actually down compared to $2012 .{ }^{17}$ In the 2016 cycle, all candidates for

12 An Inside Look At Congressional Fundraising, THE Gov. AfF. InST. AT GEORGETOWN U. (June 26, 2013), https://gai.georgetown.edu/an-inside-look-at-congressional-fundraising/ (quoting Ryan Lizza's live tweeting of Congressional fundraising calls).

13 Citizens United v. FEC, 558 U.S. 310, 310 (2010); Daniel P. Tokaji \& Renata E. B. Strause, The New Soft Money: Outside Spending In Congressional Elections, Оніо Sт. U. MORITZ C. OF L. 13 (2014), http://moritzlaw.osu.edu/thenewsoftnioney/wp-content/uploads /sites/57/2014/06/the-new-soft-money-WEB.pdf ("Some respondents, including a few candidates, felt pressure to raise more money than ever before [Citizens United] and named outside spending as the cause. This was particularly true where the respondent had a view from the Senate side.").

14 Glenn W. Richardson Jr., Pulp Pol. How Pol. Advert. Tells the Stories of Am. PoL. 156 (2d ed. 2008) ("More broadly, the cost of [tv] advertising is implicated in the incessant chase for campaign cash that preoccupies elected officials throughout their tenure in office. No sooner have they won election than they must begin soliciting funds for their next race. The result, some suggest, is an influence peddling bazaar, or as former U.S. Senator Max Cleland once put it, a democracy 'more like an auction than an election."'); TED BRADER, Campaigning for Hearts and Minds How Emotional Appeals in Pol. Ads Work 13 (2006) ("Over the past half century in American politics, television ads have become the principal tool of contemporary electioneering. Spending on ads accounts for the largest share of the budget for almost all presidential, gubernatorial, and congressional campaigns.").

15 Senator Richard G. Lugar (Ret.), Address at the Duke University Sanford School of Public Policy: Embracing Governance over Partisanship (Feb. 12, 2013) (transcript available at http://www.thelugarcenter.org/newsroom-events-51.html) ("But perhaps the most potent force driving partisanship is the rise of a massive industry that makes money off of political discord. This industry encompasses cable news networks, talk radio shows, partisan think tanks, direct mail fundraisers, innumerable websites and blogs, social media, and gadfly candidates and commentators. Many of these entities have a deep economic stake in perpetuating political conflict. They are successfully marketing and monetizing partisan outrage.").

16 Ashley Balcerzak, UPDATE: Federal Elections to Cost Just Under \$7 billion, CRP Forecasts, CENT. FOR ReSPONSIVE POL. (Nov. 2, 2016), https://www.opensecrets.org/news/2 016/11/update-federal-elections-to-cost-just-under-7-billion-crp-forecasts/.

17 Cf. Center for Responsive Politics, 2016 Election Overview, OPEN SECRETS (May 18, 2017), https://www.opensecrets.org/overview/ (listing the cost of the 2016 presidential race 
the House raised $\$ 1,033,545,524$ and all candidates for the Senate raised $\$ 667,687,881 .{ }^{18}$ Thus, the primary focus of this Article will be on the fundraising burdens experienced by incumbent Members of Congress. This is not to argue, however, that Congressional challengers or candidates for the Presidency are off the hook. All federal candidates, except for those who can afford to self-finance a multi-million-dollar race, are stuck on the same fundraising treadmill, and are consumed by what has been euphemistically referred to as "call time."

Retiring Republican Congressman Reid Ribble pointed the finger at Citizens United as part of the problem telling 60 Minutes in 2016,

[i]f members would be candid, there's a lot of frustration centered around it. And some of this is the result of Citizens United, the Supreme Court decision that opened up really corporate dollars into the system. And so, if you want to have your own voice, if you want your voice to be heard as opposed to some outside group speaking for you, you better-you better do your job and raise enough money that you can.

Thus, in a post-Citizens United environment where outside political spenders flourish, they need to raise funds to pay for the communication with voters that they want in order for federal candidates to keep control of their own message. And the data shows that while the amount of fundraising for Congress has steadily gone up in each election cycle between 2000 ( $\$ 1$ billion for all House and Senate candidates) and 2012 ( $\$ 1.9$ billion for all House and Senate candidates); the cost has only slightly dipped in 2014 and 2016 to a "new normal" of $\$ 1.7$ billion for all House and Senate candidates. The biggest jump in Congressional fundraising dollars was in 2010. Whether this was caused by Citizens United or only coincided with Citizens United is a matter of debate.

at $\$ 1,312,110,914)$, with Center for Responsive Politics, 2012 Election Overview, OPEN SECRETS (July 15, 2013), https://www.opensecrets.org/ overview /index.php?display $=$ T\&type $=$ A\&cycle $=2012$ (showing the cost for the presidential race in 2012 at $\$ 1,372,896,499)$.

18 Center for Responsive Politics, 2016 Election Overview, OPEN SECRETS (Apr. 15, 2018). https://www.opensecrets.org/overview/.

19 Norah O'Donnell, Are Members of Congress Becoming Telemarketers?, CBS NEwS (Apr. 24, 2016), http://www.cbsnews.com/news/60-minutes-are-members-of-congress-beco ming-telemarketers/. ("Norah O'Donnell: Are you the only one who feels that way? Rep. Reid Ribble: No. No."). 


\section{Fundraising by Candidates for Congress 2000-2016}

\begin{tabular}{|c|c|c|c|}
\hline All Candidates & $\mathbf{2 0 0 0}$ & $\mathbf{2 0 0 2}$ & $\mathbf{2 0 0 4}$ \\
\hline House & $601,053,650$ & $\$ 658,236,440$ & $\$ 707,200,663$ \\
\hline Senate & $\$ 482,134,638$ & $\$ 397,288,911$ & $\$ 580,321,542$ \\
\hline Total & $\$ 1,083,188,288$ & $\$ 1,055,525,351$ & $\$ 1,287,522,205$ \\
\hline
\end{tabular}

\begin{tabular}{|c|c|c|c|}
\hline All Candidates & $\mathbf{2 0 0 6}$ & $\mathbf{2 0 0 8}$ & $\mathbf{2 0 1 0}$ \\
\hline House & $\$ 878,070,492$ & $\$ 993,126,172$ & $\$ 1,096,535,924$ \\
\hline Senate & $\$ 646,141,715$ & $\$ 499,354,330$ & $\$ 824,399,235$ \\
\hline Total & $\$ 1,524,212,207$ & $\$ 1,492,480,502$ & $\$ 1,920,935,159$ \\
\hline
\end{tabular}

\begin{tabular}{|c|c|c|c|}
\hline All Candidates & $\mathbf{2 0 1 2}$ & $\mathbf{2 0 1 4}$ & $\mathbf{2 0 1 6}$ \\
\hline House & $\$ 1,095,278,481$ & $\$ 1,026,176,171$ & $\$ 1,033,545,524$ \\
\hline Senate & $\$ 761,201,126$ & $\$ 711,064,232$ & $\$ 667,687,881$ \\
\hline Total & $\$ 1,856,479,607$ & $\$ 1,737,240,403$ & $\$ 1,701,233,405$ \\
\hline
\end{tabular}

Fundraising by incumbent Members of Congress who were up for reelection showed a similar pattern. In 2000 all Congressional incumbents raised $\$ 485$ million and in 2016 all Congressional incumbents raised $\$ 908$ million. Incumbents certainly raised more money after 2010's Citizens United. Again, its exact role in causality is debatable.

Fundraising by Incumbent Members of Congress 2000-2016 ${ }^{21}$

\begin{tabular}{|c|c|c|c|}
\hline Members Only & $\mathbf{2 0 0 0}$ & $\mathbf{2 0 0 2}$ & $\mathbf{2 0 0 4}$ \\
\hline House & $\$ 356,525,996$ & $\$ 375,442,400$ & $\$ 452,308,551$ \\
\hline Senate & $\$ 129,469,197$ & $\$ 132,742,417$ & $\$ 170,694,789$ \\
\hline Total & $\$ 485,995,193$ & $\$ 508,184,817$ & $\$ 623,003,340$ \\
\hline
\end{tabular}

20 The source of this data is the Center for Responsive Politics' Election Overview for 2000, 2002, 2004. 2006, 2008, 2010, 2012, 2014, and 2016 (https://www.opensecrets .org/overview/index.php?display $=$ T\&type $=$ A\&cycle $=2000)$. Select a new cycle date to see the underlying data.

21 The source of this data is the Center for Responsive Politics' Election Overview for 2000, 2002, 2004. 2006, 2008, 2010, 2012, 2014, and 2016 (https://www.opensecrets .org/overview/index.php?display $=T \&$ type $=\mathrm{R} \&$ cycle $=2000)$. Select a new cycle date to see the underlying data. 


\begin{tabular}{|c|c|c|c|}
\hline Members Only & $\mathbf{2 0 0 6}$ & $\mathbf{2 0 0 8}$ & $\mathbf{2 0 1 0}$ \\
\hline House & $\$ 529,341,321$ & $\$ 577,082,977$ & $\$ 622,567,007$ \\
\hline Senate & $\$ 276,385,202$ & $\$ 221,624,592$ & $\$ 231,114,120$ \\
\hline Total & $\$ 805,726,523$ & $\$ 798,707,569$ & $\$ 853,681,127$ \\
\hline
\end{tabular}

\begin{tabular}{|c|c|c|c|}
\hline Members Only & $\mathbf{2 0 1 2}$ & $\mathbf{2 0 1 4}$ & $\mathbf{2 0 1 6}$ \\
\hline House & $\$ 652,359,834$ & $\$ 632,538,085$ & $\$ 645,225,227$ \\
\hline Senate & $\$ 223,737,097$ & $\$ 283,415,693$ & $\$ 263,414,588$ \\
\hline Total & $\$ 876,096,931$ & $\$ 915,953,778$ & $\$ 908,639,815$ \\
\hline
\end{tabular}

Participating in the fundraising arms race is rational behavior for most candidates because predictably the candidate with the bigger campaign war chest wins the election. ${ }^{22}$ This fundraising treadmill leads to deleterious effects including dependence on lobbyists for fundraising assistance and for policy making, as well as an unhealthy reliance on a small oligarchic subset of American political donors. ${ }^{23}$

Without public financing for Congressional candidates, the only way to avoid the time suck of fundraising is to be independently

22 Bob Biersack, The Big Spender Always Wins?, OpEn SECRETS (Jan. 11, 2012), https://www.opensecrets. org/news/2012/01/big-spender-always-wins/ ("It's a bedrock truth of money and politics: The biggest spender almost always wins ... Even during the most competitive cycles, when control of Congress is up for grabs, at the end of the day the candidates who spend the most usually win eight of 10 Senate contests and nine of 10 House races."); Center for Responsive Politics, Money Wins Presidency and 9 of 10 Congressional Races in Priciest U.S. Election Ever, OPEN SECRETS (Nov. 5, 2008), http://www.opensecrets .org/news/2008/11/money-wins-white-house-and/; see also Hearing on Campaign Finance Reform Before the H. Committee on House Administration, 107th Cong. (May 1, 2002) (statement of Rep. Christopher Shays: "We are in an arms race that is called the money race. It is for real. It is not an imaginary thing. It is not getting better. It is getting worse.").

23 Lee Drutman, The Political 1\% of the 1\% in 2012, SunLight Foundation (June 24, 2013, 9:00 AM), https://sunlightfoundation.com/2013/06/24/1pct_of_the_1pct/ ("One sign of the reach of this elite ' $1 \%$ of the 1\%': Not a single member of the House or Senate elected last year won without financial assistance from this group. Money from the nation's 31,385 biggest givers found its way into the coffers of every successful congressional candidate. And 84 percent of those elected in 2012 took more money from these $1 \%$ of the $1 \%$ donors than they did from all of their small donors (individuals who gave \$200 or less) combined."); see id. ("Overall, a total of 32 members of Congress (24 House members and eight Senators) elected in 2012 got at least 25 percent of their total funds from $1 \%$ of the $1 \%$ donors. And 72 House members and 19 senators got at least 20 percent of their funds from these donors."); Derek Thompson, Why the GOP's Dream of Tax Reform Is (Probably) Doomed, THE ATLANTIC (Nov. 9, 2017), https://www.theatlantic.com/business/archive/2017/11/gop-taxcut/545450/ ("About 0.5 percent of the U.S. population makes up 68 percent of contributions to political candidates, parties, or PACs, according to Open Secrets, a nonprofit that studies political donations."). 
wealthy. ${ }^{24}$ And yet, the Roberts' Supreme Court seems particularly tone deaf to arguments about preserving the ability of a non-wealthy incumbent elected officials to do his or her official duties under Article I of the Constitution.

This Article will first discuss how the current Supreme Court treats arguments about candidates' time; then it will explore how Members of Congress conceptualize the burden of fundraising; next, it will look at what data on fundraising reveals about who rises through the ranks in Congress; then it will explain how cognitive scientists predict multitasking impacts effectiveness at work; and finally the piece will look at how dialing for dollars often leads lawmakers to rely on wealthy donors and lobbyists to finance their campaigns, who are all too eager to have an impact on future policy choices.

\section{The CURRENT SHORTSIGHTED JURISPRUDENCE ON CANDIDATE TIME}

In 1976, in Buckley v. Valeo, the seminal Supreme Court case that has defined the contours of campaign finance law in the United States for 40 years, Justice Byron White offered a prophetic warning in dissent. Justice White worried that by limiting campaign contributions and leaving political expenditures unregulated in the post-Watergate reform legislation known as the Federal Election Campaign Act ("FECA 1974 "), ${ }^{25}$ the Supreme Court had thereby relegated political candidates to an endless treadmill of campaign fundraising. ${ }^{26}$ Justice White was not a jurist pontificating from idle conjecture when he wrote his admonition in Buckley. Instead, Justice White was drawing on his own lived experience as a fundraiser and campaigner for President John F. Kennedy's

24 Daniel Weiss, Keeping the Money Coming, CAMPAigns \& Elections (May 16, 2011), https://www.campaignsandelections.com/campaign/keeping-money-coming (responding to the question, "[h]ow is the role of candidates themselves changing in fundraising? Do you find that it's a struggle to get them to devote the amount of face time or phone time with potential donors that is necessary? ... "Robichaud: At the end of the day, 90 percent of candidates try to avoid having to dial for dollars. They don't like it; it's like going to the dentist for them. And so if they want to get out of fundraising, I usually tell them that they have to write a big check to their campaign. That's the only way they're going to get out of raising the money.").

25 Larry J. Sabato \& Glenn R. Simpson, Dirty Little Secrets The Persistence of Corruption IN AM. Pol. 15 (1996) ("In its landmark ruling Buckley v. Valeo, the Court eliminated expenditure limits as violations of first Amendment rights.").

26 Buckley v. Valeo, 424 U.S. 1, 265 (1976) (White, J. concurring in part and dissenting in part) ("There is nothing objectionable indeed it seems to me a weighty interest in favor of the provision in the attempt to insulate the political expression of federal candidates from the influence inevitably exerted by the endless job of raising increasingly large sums of money. I regret that the Court has returned them all to the treadmill."); LAWRENCE LESSIG, REPUBLIC, Lost How Money CoRrupts Congress-AND A Plan to Stop It 96 (2011) (quoting Josh Rosenkranz) (“it[] was a system that turned 'decent, honest politicians [into] junkies.'”). 
contentious 1960 election. ${ }^{27}$ Justice White's concerns about the burdens of fundraising were shared by President Kennedy, the man he helped elect. After President Kennedy won the White House, he too "bemoaned the 'great financial burdens' on campaigns due largely to the costs of television advertising. It meant that candidates' chances were largely 'governed by their success as fundraisers." 28

Two score and two years after Buckley, the day-to-day schedules of America's elected officials are evidence that Justice White's prediction in Buckley came true. ${ }^{29}$ Moreover, elected officials' day-to-day experiences should be reconsidered by the current Supreme Court as having constitutional significance. ${ }^{30}$ The Justices need to, at long last, realize that there is a compelling state interest in protecting incumbent candidates' time so that they have a chance to govern effectively. ${ }^{31}$ The Supreme Court must grapple with the "time drought" that incumbent candidates experience when they lose precious hours in the day that should be devoted to governing, but rather is spent dialing for dollars for their next reelection campaigns. ${ }^{32}$

The last occasion that the U.S. Supreme Court considered the "saving the candidates' time" rationale for campaign finance reform, the Court rejected it. This is a shame because the Court's obstinacy on this point prevents the Congress from enacting reforms that might cap the amount political candidates could spend on an election, as well as stymying public financing systems that include triggered matching funds. ${ }^{33}$ The Court's most recent opportunity to hear arguments about

27 Byron R. White, OYEZ, https://www.oyez.org/justices/byron_r_white (last visited May 10, 2018)

28 John Nichols \& Robert W. McChesney, Dollarocracy, How the Money and Media EleCtion COMPLEX Is Destroying AmERICA 24 (2013) (quoting John F. Kennedy).

29 Ciara Torres-Spelliscy, Unstoppable Campaign Fundraisers, BRENNAN CENTER BLOG (Oct. 3, 2013), https://www.brennancenter.org/blog/unstoppable-campaign-fundraisers.

30 Usha R. Rodrigues, The Price of Corruption, 31 GA. L. J. \& PoL. (This Journal doesn't have an exact bluebook citation in the book - flagging for your decision on if to just leave it like this) 45, 81 (2015) ("In the McCutcheon plurality's view, a heightened responsiveness to donors is a good thing. But the unstated cost of access is its flipside: the diminished voice of non-donors. As Professor Vincent Blasi observes, campaign finance restrictions have created a world that pressures candidates' time in a manner that leaves little room for general constituent service.").

31 This Author is not the first to argue there is a compelling governmental interest in protecting the time of candidates. See generally Alexander, supra note 2, at 699.

32 Zephyr Teachout, Corruption in Am. From Benjamin Franklin's SnufF Box to Citizens United 209 (2014) ("The unlimited spending [after Buckley] led to even more candidate time fund-raising.").

33 Campaign Finance Reform: Proposals Impacting Broadcasters, Cable Operators and Satellite Providers: Hearing on the Shays-Meehan Campaign Finance Reform Bill Before the H. Comm. on Energy and Commerce, Subcomm. On Telecommunications and the Internet, 107th Cong. (2001) (statement of Edward J. Markey, U.S. Congressman, Massachusetts: "I 
preserving candidates' time occurred in a 2006 case called Randall $v$. Sorrell in which the Justices considered the constitutionality of a Vermont campaign law that mimicked the structure of the original Federal Election Campaign Act Amendments of 1974 (FECA 1974). Vermont's law had both low contribution limits and expenditure limits (similar to FECA 1974). ${ }^{34}$ The Randall case was an attempt by litigants to overturn Buckley v. Valeo from the left. It failed.

The Randall case was up on appeal from the Second Circuit, which had "held that all of the [Vermont] Act's contribution limits are constitutional. It also held that the Act's expenditure limits may be constitutional. It found those limits supported by two compelling interests, namely, an interest in preventing corruption or the appearance of corruption and an interest in limiting the amount of time state officials must spend raising campaign funds." ${ }^{35}$ But the Supreme Court in Randall reversed the appeals court, finding both Vermont's contribution limits unconstitutionally low and its expenditure limits impermissible according to Buckley's precedent.

In Randall, the Supreme Court also specifically rejected protecting the candidate's time as a compelling state interest stating: "[Vermont] advance[s] as a ground for distinction a justification for expenditure limitations that, they say, Buckley did not consider, namely, that such limits help to protect candidates from spending too much time raising money rather than devoting that time to campaigning among ordinary voters. We find neither argument persuasive." 36 In particular, Justice Breyer, writing for the Court in Randall stated:

In our view, it is highly unlikely that fuller consideration of this time protection rationale would have changed Buckley's result. The Buckley Court was aware of the connection between expenditure limits and a reduction in fundraising time .... And, in any event, the connection between high campaign expenditures and increased fundraising demands seems perfectly obvious.

Thus, in a few short sentences, the Supreme Court brushed aside concerns about the time candidates-especially incumbents-spend fundraising instead of attending to other aspects of governing, or even other aspects of campaigning like interacting face-to-face with a broad

have long supported public financing as a way to help limit the overall cost of campaigns and to limit the amount of time and energy that politicians must exert in fundraising.").

34 VT. STAT. ANN. tit. 17, § 2801 (West 1997) (repealed 2013).

35 Randall v. Sorrell, 548 U.S. 230, 240 (2006) (referring to Landell v. Sorrell, 382 F.3d

91 (2004)) (emphasis added).

36 Id. at 243.

37 Id. at 245-46. 
economic cross-section of voters. ${ }^{38}$ Consequently, because of Randall, the Supreme Court would have to change its approach to recognize that protecting a candidate's time is a compelling state interest that could justify a new campaign finance law as some federal Circuit Courts have done before. ${ }^{39}$ Below, this Article discusses why Supreme Court Justices and other judges throughout America should take the matter of a candidate's time more seriously. While 2006 is relatively recent, the composition of the Supreme Court has changed. One Justice has died and two Justices have retired. As a result, three new Justices have joined: Justices Kagan, Sotomayor and Gorsuch. Each could offer an entirely new perspective.

\section{Federal Elected OfFicials ARE WATCHING Their DAys Tick AWAY AS THEY FUNDRAISE}

As is evident from the position of the Supreme Court in Randall and Buckley, Article III judges can be dismissive of just how time-consuming fundraising has become. One possible reason for this lack of empathy across the co-equal branches of government is that Article III judges never face elections and enjoy lifetime appointments. And it is possible that just like members of the general public, judges may misperceive the scope of the problem. Polling in 2017 revealed that Americans believed the average Members of Congress spent only ten hours a week fundraising - this is a considerable underestimate. ${ }^{40}$

But what do elected Article I office holders think about the fundraising burden? Many legislators are on the record despising the practice and the frustration is bipartisan. For instance, in the Summer of 2016, Democratic Congressman John Sarbanes addressed the Ford Foundation. ${ }^{41}$ Congressman Sarbanes lamented about what he called "the

38 The Supreme Court was not alone in discounting arguments about candidates' time. See Kruse v. City of Cincinnati, 142 F.3d 907, 916-17 (6th Cir. 1998) ("The need to spend a large amount of time fundraising is a direct outgrowth of the high costs of campaigns. However, because the government cannot constitutionally limit the cost of campaigns, the need to spend time raising money, which admittedly detracts an officeholder from doing her job, cannot serve as a basis for limiting campaign spending.").

39 Rosenstiel v. Rodriguez, 101 F.3d 1544, 1553 (8th Cir. 1996) (“[T]he State seeks to promote. . .a diminution in the time candidates spend raising campaign contributions, thereby increasing the time available for discussion of the issues and for campaigning. It is well settled that [this] government interest [is] compelling."); see also Vote Choice, Inc. v. DiStefano, 4 F.3d 26, 39 (1st Cir. 1993).

40 Sarah Kleiner, Democrats Say Citizens United Should Die. Here's Why That Won't Happen, TIME (Aug. 31, 2017), http://time.com/49225/democratscitizenunited/ (“According to the Center for Public Integrity-Ipsos poll, 58 percent of respondents believe congressional members spend 10 hours or less a week fundraising. But members, on average, spend 20-to30 hours per week fundraising, according to research by Issue One.”).

41 Congressman John Sarbanes, Remarks at Scholars Strategy Network: Purchasing 
time suck" caused by the magnitude of political fundraising he had to do on a regular basis. In other words, the time Congressman Sarbanes spent raising campaign cash was time he could not meet with a constituent, attend a committee hearing to mark-up legislation, or even cast a vote on the floor of Congress - presumably all the actions his constituents elected him to do. Also, in 2016, Republican Congressman Walter Jones similarly stated in an interview, "[e]verything has gotten out of hand up here. It's all about raising money." 42

\section{A. Pre-Citizens United Fundraising}

House Minority Leader Robert Michel once described having to attend at least five fundraisers a night. ${ }^{43}$ Now of course, each lawmaker will have his or her own fundraising routine. Some will spend more time fundraising, either because they enjoy the process, or because they feel that they will not be reelected without it. Others, who loathe the practice or are lucky enough to hold a "safe seat," may do less of it. ${ }^{44}$ Without a comprehensive survey across all candidates, no one can know with any certainty that the stories about fundraising that end up in the press are representative or outliers. One reform that would be helpful to voters and researchers alike is requiring members of Congress to report exactly how much time they spend fundraising. ${ }^{45}$

Political spending on federal campaigns has grown since the 1980s. One study found that campaign spending between 1984 and 2012 had grown a jaw dropping 555\%. ${ }^{46}$ Consequently, the fundraising time

Power (June 17, 2016).

42 Michael Beckel, Meet The GOP Congressman Who Wants To Overturn 'Citizens United' Walter Jones Says Fundraising Has 'Gotten Out Of Hand' In Washington, CENT. FOR PUB. INTEGRITY (Jan. 21, 2016), https://www.publicintegrity.org/2016/01/21/19154/meet-gop -congressman-who-wants-overturn-citizens-united.

43 Alexander, supra note 2, at 676 ("The time you spent raising money, and the number of fund-raising events I was obligated to attend or at least stop by-gosh, you'd have five or six a night. It just wears on you.”).

44 Martin Schram, Speaking Freely: Former Members of Congress Talk about Money IN Politics 18 (1995) (quoting Sen. Wyche Fowler (D-Georgia): "I've had this discussion with my colleagues. They say, 'Goddammit, I've got to go ask these people, and if I ask them, what are they going to ask of me?' . . There are exceptions - some [members] who love to raise money, love to schmooze with those that give.").

45 Brent Ferguson, Congressional Disclosure of Time Spent Fundraising, 23 CORNELL J. OF L. AND PUB. POL'Y 1, 4 (2013) ("The simplest version of such a law . . . is a requirement that legislators disclose the amount of time they spend fundraising .... Making the information accessible to the public would increase awareness of the volume of fundraising that occurs, perhaps spurring more calls for change.").

46 Michael Scherer, Pratheek Rebala, \& Chris Wilson, Campaign Inflation Calculator, TiME (Oct. 23, 2014), http://time.com/3534117/the-incredible-rise-in-campaign-spending/ ("Since the mid-1980s, the amount dumped on elections by campaigns and outside groups, as measured by the Federal Election Commission, has grown 555 percent - faster than even the 
crunch has been festering for decades. As conservative political scientist Larry Sabato warned two decades ago, the scandalous nature of fundraising has become routinized and normalized through repetition:

[S]candal has become so routine that it no longer seems scandalous. Donations of $\$ 1$ million or more in obvious protection money from individuals and corporations whose motives are no more noble than [convicted fraudster Charles] Keating's are no longer news ... . and financiers . . . cynically lard the coffers of both political parties so that they will come out on top no matter who wins at the polls. ${ }^{47}$

In the mid-1990s, Martin Schram gathered quotes about campaign finance from individuals who recently retired from serving in Congress, both in the House of Representatives and in the Senate. Several Representatives and Senators that spoke to Mr. Schram highlighted the problem of the time-consuming nature of political fundraising for incumbents. For instance, Senator Dennis DeConcini reported, " $[t]$ he worst thing about it is that members have to spend so much time in the pursuit of campaign finances that I think their ability to do really their best as legislators is jeopardized. And I'm a good example ... [y]ou are constantly out there grazing [for money]."48 Senator Howard Metzenbaum did not mince words about how much he detested fundraising. Senator Metzenbaum reported to Mr. Schram:

If there's $\$ 7.5$ million. . . and if you did get $\$ 1,000$ from every person, it would be 7,500 individuals that you had to talk to convince to send $\$ 1,000$. Follow up to send thank-yous ... hours upon hour .... You'd like to be spending your time on legislation - on the floor of the Senate, in committees, with staff, deciding what other projects you want to be involved in .... It becomes very time-consuming, very arduous. And a pain in the butt. ${ }^{49}$

And Congressman Vin Weber noted, in a similar vein to $\mathrm{Mr}$. Schram, "I do think that the amount of time people have to put into raising money is a serious problem in the country .... There's no way you can prove its impact on the quality of the Congress's work .... But when the members making decisions can't devote serious quality time to serious decisions, it has to [result in] a lower quality of work." ${ }^{50}$ Others like Congressman Mel Levine who ran for a Senate seat were more certain that fundraising had negatively impacted their job performance. As Congressman Levine related, "I did raise a lot of money, particularly in my Senate race, and it just drained my time and ability to do anything

alarming increases in the costs of health care and private college tuition.”).

47 SABATO \& Simpson, supra note 25, at 24.

48 SCHRAM, supra note 44, at 40 (quoting Sen. Dennis DeConcini (D-Arizona)).

49 SChRAM, supra note 44, at 43 (quoting Sen. Howard Metzenbaum (D-Ohio)).

50 SchrAm, supra note 44, at 38 (quoting Rep. Vin Weber (R- Minnesota)). 
else. It just crippled my ability to do my job properly in my final term ....." ${ }^{51}$ Congressman Jim Bacchus agreed that fundraising could get in the way of legislating, arguing "while all of this [fundraising] is going on, you're not reading pending legislation. And you're not doing what you were elected to do., 52

Having legislative work bend around fundraising was a problem noted by former Senate Majority Leader George Mitchell whose job included setting the Senate's schedule:

One of the most common reasons [for a request to reschedule a floor vote by a Senator] is that they are either holding or attending a fund-raising event .... If I put all the requests together, the Senate would never vote. I once had my staff keep a list of such requests on one day . . . and had I honored all the requests, there could not have been a vote that day. It covered the period from nine a.m. until midnight."

Thus, if fundraising was allowed to pause all legislative functions, it could debilitate the legislative branch of the government.

The new millennium's technologies like the Internet ${ }^{54}$ did not stop the fundraising treadmill for Members of Congress. ${ }^{55}$ The public knows this because lawmakers have testified under oath about the impact of the continued fundraising burdens. For example, in 2001 Congressman Tom Sawyer testified: "[t]his incessant money chase that everybody has referred to, to fund ever more costly campaigns diverts members' attention from important duties and diminishes public trust. Members of the House today operate in a state of perpetual campaigning." 56 In 2002, only a year later, Congressman Richard Gephardt testified that:

I have talked with colleagues on both sides of the aisle about

51 SChrAM, supra note 44, at 42 (quoting Rep. Mel Levine (D-California)).

52 SCHRAM, supra note 44, at 45 (quoting Rep. Jim Bacchus (D-Florida)).

53 SCHRAM, supra note 44, at 37-38 (quoting Senate Majority Leader George Mitchell (D-Maine)).

54 Weiss, supra note 24 (responding to the question, "[a]s fundraisers, what do you see as your major challenges approaching the 2012 campaign cycle?" . . . Linder: . . . one of the observations that I've had with online fundraising is it is absolutely not a panacea. You still have to have a hot candidate or a hot cause to get people to respond to an e-mail or drive themselves to a website to make a donation. People just don't go looking for reasons to make political contributions .... Fundraising is still turning over rocks - creating that relationship, whether it is by mail, through events, or through personal calls.").

55 Brandon Lewis, Why Candidates Hate Fundraising, CAMPAIGNS AND EleCtions (Oct. 1, 2013), https://www.campaignsandelections.com/campaign-insider/why-candidates-hatefundraising. ("Fundraising is the one area of campaigning that consistently and continually offers a steady stream of rejection, refusal and dismissal from friends, associates and total strangers.").

56 Campaign Finance Reform: Proposals Impacting Broadcasters, Cable Operators and Satellite Providers: Hearing Before the Subcomm. on Telecomms. and the Internet of the H. Comm. on Energy and Commerce, 107th Cong. 11 (2001) (statement of Rep. Tom Sawyer, Member, H. Comm. on Energy and Commerce). 
this endless chase for more and more money. The creative energies of our best and brightest public servants in both parties are invariably being directed towards keeping up in order to be competitive and raise more and more money to get there. Our focus should be on addressing and solving the problems that confront the American people, not meeting quarterly fund-raising goals. This is the politics of mutually assured destruction ...

And yet, since Congressman Gephardt's remarks, fundraising pressures for incumbents have likely worsened because the Supreme Court has loosened restrictions on campaign finance laws since $2006 .^{58}$

\section{B. Post-Citizens United Fundraising}

In addition to the 2006 Randall decision highlighted above, one of the key deregulatory decisions from the Roberts Supreme Court was the 2010 Citizens United v. FEC ruling. ${ }^{59}$ It was quickly followed with Bennett and McCutcheon, which further deregulated the rules governing money in politics. ${ }^{60}$ Notably, Citizens United is about independent spending and not the direct contributions that is the focus of this Article. However, the impact of post-Citizens United independent spending is an increased pressure on candidates to fundraise so that they can get out their own message among the din of newly empowered spenders like Super PACs. ${ }^{61}$ As Lee Drutman explained, "So in the post-Citizens United campaign finance environment of unlimited outside spending, not only do members running for reelection have to commit seemingly endless hours in the unpleasant uphill battle of begging rich people for money, but their efforts can instantly be dwarfed by outside spending (from even richer people) that will then shape the contours of the race by running ads

57 Campaign Finance Reform: Hearing Before the H. Comm. on H. Admin., 107th Cong. 5 (2002) (statement of Rep. Richard Gephardt, Minority Leader, H.R.).

58 Randall, 548 U.S. at 230 (invalidating Vermont's contribution and expenditure limits); FEC v. Wisconsin Right to Life, Inc., 551 U.S. 449 (2007) (narrowing the definition of electioneering communications); Davis v. FEC, 554 U.S. 724 (2008) (invalidating the millionaire's amendment); Citizens United v. FEC, 558 U.S. 310 (2010) (invalidating the ban on corporate political expenditures); Ariz. Free Enter. Club's Freedom Club PAC v. Bennett, 131 S.Ct. 2806 (2011) (invalidating the triggered matching funds in Arizona's public financing system); McCutcheon v. FEC, 134 S. Ct. 1434 (2014) (invalidating an aggregate limit for individual donations).

59 Citizens United, 558 U.S. at 310. FN 59-61 belong on the previous page.

60 Bennett, 546 U.S. at 753; McCutcheon, 134 S. Ct. at 1462.

61 Lee Drutman, The Political 1\% of the 1\% in 2012, SunLight Foundation (June 24, 2013), https:// sunlightfoundation.com/2013/06/24/1pct_of_the1pct/ ("In the first presidential election cycle since the Supreme Court's decision in Citizens United v. FEC, candidates got more money from a smaller percentage of the population than any year for which we have data, a new analysis of 2012 campaign finance giving by the Sunlight Foundation shows. These donors contributed 28.1 percent of all individual contributions in the 2012 cycle, a record high."). 
'independent' of the candidates." 62

The cost of elections has increased markedly between 2006 when Randall was decided and 2016. According to the Center for Responsive Politics, in 2006, the total cost of Congressional races was $\$ 2,852,658,140$, but this cost shot up to $\$ 4,057,519,568$ in 2016 with new Super PAC spending included. ${ }^{63}$ In 2006, the typical winner in a House seat spent $\$ 1.2$ million. ${ }^{64}$ And in 2016 , the typical winner in a House seat spent $\$ 1.5$ million. ${ }^{65}$ So how dire is the "time suck" problem since Citizens United ${ }^{66}$ That difference may not seem large, but recall that the additional $\$ 300,000$ must be raised within the hard money limits of $\$ 2,100$ to $\$ 2,700$ per donor (depending on the year). Not surprisingly, many political donors have reported amplified pressure to contribute over this time frame. ${ }^{67}$ Yet one limited survey in 2013 of twenty-five members of the House found that these members spent less than twenty percent of their time fundraising, or roughly a single day a week. ${ }^{68}$ But again, this

62 Lee Drutman, Why So Many Members Of Congress Are Retiring: It's A Miserable Job, And Campaigning For It Is Awful, Vox (Feb. 1, 2018, 11:40 AM), https://www.vox.com /polyarchy/2018/2/1/16958988/congress-members-retiring-why.

63 Cost of Election, CENT. FOR RESPONSIVE POL. (https://www.opensecrets.org/overview /cost.php) (last visited May 10, 2018).

64 Election Trends, CENT. FOR RESPONSIVE POL. (2006), https://www.opensecrets.org/ overview/election-trends.php?cycle=2006 (last visited May 10, 2018).

65 Michael J. Malbin, Does The Opening Predict A Wave?, Brookings (July 24, 2017), https://www.brookings.edu /blog/fixgov/2017/07/24/does-the-opening-predict-a-wave/.

66 Jane Mayer, Dark Money: The Hidden History of THE Billionaires Behind the RisE OF THE RADICAL Right 313-14 (2016) (“. . . the 2012 election was a tipping point of sorts. Not only was it by far the most expensive election in the country's history; it was also the first time since the advent of modern campaign-finance laws when outside spending groups, including super PACs and tax-exempt nonprofit groups, flush with unlimited contributions from the country's richest donors, spent more than $\$ 1$ billion to influence federal elections. And when the spending on attack ads run by nonprofits was factored in, outside spending groups might well have outspent the campaigns and the political parties for the first time.").

67 Monica Youn, The Fair Elections Now Act: A Comprehensive Response to Citizens United, BRENNAN CENT. FOR JUST. (Apr. 12, 2011), https://www.brennancenter.org/analysis/ fair-elections-now-act-comprehensive-response-citizens-united. ("According to an October 2010 poll by the Committee for Economic Development, $48 \%$ of business leaders state that the level of pressure placed on them to make political contributions has increased since 2008, with $28 \%$ saying it has 'increased a lot."').

68 Life in Congress: The Member Perspective, Cong. MGMT. Found. \& Soc'y For Human Resource MGMT. 19 (2013), http://www.congressfoundation.org/storage/docum ents/CMF_Pubs/life-in-congress-the-member-perspective .pdf ("The finding that may surprise some observers is that Members are spending less than $20 \%$ of their time in an average week on political and campaign activities (which includes fundraising and attending campaign events in Washington, D.C., and in the district)."); but see David Hawkings, Dialing for Dollars: The Other Money Matter on Their Minds This Week, Roll CALL (Mar. 18, 2013), http://www.rollcall.com/news/hawkings/dialing-for-dollars-the-other-money-matter-on-thehills-mind-this-week\#sthash.bzKtuyZV.dpuf (commenting on the Life in Congress report: "[When fundraising time was] [c] ombined with the hours devoted to media relations, the 
sample may not be representative of the average Member of Congress. By contrast, The Boston Globe in a 2013 article about freshman Members of Congress reported: “'It may not be exactly like the Bataan Death March, but there are some similarities,' said one freshman representative who did not want to speak on the record for fear it would harm his campaign."69

Again, there is not a comprehensive survey that would provide a definitive answer regarding how much the average Members of Congress spends on fundraising, but we do have limited evidence from the press. Recent press reports of leaked fundraising memos and power points have revived the issue of just how much time is spent by federal candidates on fundraising. ${ }^{70}$

If technologies, such as emailed campaign solicitations, were supposed to solve the problem of the candidate fundraising burden, they have not. ${ }^{71}$ President Barack Obama's experience shows that emailed solicitations are made in addition to, not instead of, other methods of appeals. On top of the prodigious number of emails from the Obama campaign soliciting funds from potential donors, during his reelection campaign in 2012 President Obama attended over 200 fundraisers. ${ }^{72}$ One political reporter did the math and found that during the 2012 election President Obama was at a fundraiser once every sixty hours during the

numbers grew to 26 percent of time spent on self-promotion when in Washington and 32 percent allocated that way in their districts.").

69 Tracy Jan, For Freshman in Congress, Focus is on Raising Money, Boston Globe (May 12, 2013), https://www.bostonglobe.com/news/politics/2013/05/11/freshman-lawmake rs-are-introduced-permanent-hunt-for-campaign-money/YQMMMoqCNxGKh2h0tOIF9H/st ory.html; see also Life in Congress: The Member Perspective, ConG. MGMT. Found. \& Soc'Y FOR HUMAN RESOURCE MGMT. 19 (2013) (quoting Rep. Tim Walz (D- MN)) ("“Unfortunately in the era of Citizens United fund-raising is a part of life, but the needs of your district and advocating for constituents always come first."').

70 Ryan Grim \& Sabrina Siddiqui, Call Time For Congress Shows How Fundraising Dominates Bleak Work Life, HuFF. Post (Jan. 9, 2013), http://www.motherjones.com/politics/ 2013/08/retiring-rodney-alexander-congressman-fundraising-congress/ (stating that four hours a day of call time and an hour a day for fundraisers); Andy Kroll, Retiring GOP Congressman: Fundraising Is "The Main Business" of Congress, MOTHER JONES (Aug. 8, 2013 3:02 PM), https://www.motherjones.com/politics/2013/08/retiring-rodney-alexander-co ngressman-fundraising-cong.

71 Seth Grossman, Creating Competitive and Informative Campaigns: A Comprehensive Approach to "Free Air time" for Political Candidates, 22 YALE L. \& POL'Y R. 351, 381 (2004) ("Moreover, unlike traditional, in-person fundraising, Internet fundraising does not require massive investments of candidate time and thus allows candidates to direct attention to other matters, like meeting with voters and discussing their campaign positions.").

72 Andy Kroll, Obama Has Attended, On Average, One Fundraiser Every 60 Hours While Running for Reelection, MOTHER JONES (Aug. 13, 2012 1:57 PM), http://www.mother jones.com/mojo/2012/08/obama-200-fundraisers-romney-record (stating that Obama held 203 fundraisers by August 2012). 
campaign. ${ }^{73}$ In his book, The Rise of the President's Permanent Campaign, author Brendan J. Doherty found this number was more than President Obama's five predecessors combined. ${ }^{74}$ President Obama complained about fundraising in his final State of the Union Address in 2016, noting wryly: "We have to reduce the influence of money in our politics, so that a handful of families or hidden interests can't bankroll our elections. And if our existing approach to campaign finance reform can't pass muster in the courts, we need to work together to find a real solution-because it's a problem. And most of you don't like raising money. I know; I've done it."75

Current Members of Congress are not spared the rigors of fundraising that President Obama experienced as an incumbent. If anything, Members of the House experience it on a more regular basis because they seek reelection every two years, compared to the four-year presidential cycle. House Members are stuck in the "permanent campaign" too. ${ }^{76}$ Additionally, the ability to fundraise has a significant correlation with advancement into Congressional leadership. ${ }^{77}$ The New York Times noted in an op-ed about the experiences of Congressman Steve Israel:

"It's horrific," Representative Steve Israel of New York admitted this week in announcing his retirement after eight terms. "I don't think I can spend another day in another call room making another call begging for money," he said. He estimated he has spent 4,200 hours in call rooms, plus 1,600 more at fund-raising dinners, raising $\$ 20$ million in donations.

73 Id.; see also MAYER, supra note 66, at 322 ("[Obama's 2012] campaign began encouraging supporters to give to the pro-Obama super PAC, Priorities USA . . . Obama admitted that he suffered 'from the same original sin of all politicians, which is: We've got to raise money."').

74 Brendan J. Doherty, Fundraiser in Chief, BAltimore Sun (Nov. 4, 2012), http://www.baltimoresun. com/news/opinion/oped/bs-ed-fundraising-20121104-story.html.

75 President Barack Obama, State of the Union Address (Jan. 13, 2016) (transcript available at https://obamawhitehouse.archives.gov/thepressoffice/2016/01/12/remarks-pres ident-barack-obama-\%E2\%\%93-prepared-delivery-state-union-address).

76 Emily C. Singer, What If We Didn't...Have Endless Political Campaigns?, Mic (Apr. 10, 2018), https://mic.com/articles/188447/what-if-we-didnt-have-endless-political-campaig ns\#.Ch1ZLoPHm (quoting former Rep. Israel) ("But now you're in a permanent campaign, and you go to Congress and you get nothing done. That's what's motivating so many retirements [from Congress].").

77 LESSIG, supra note 26, at 94 ("'N]ow, in both parties, leaders were chosen at least in part on their ability to raise campaign cash. Leading fund-raisers became the new leaders. Fund-raising became the new game.").

78 Editorial Board, Beggars Banquet in Congress, N.Y. Times (Jan. 7, 2016), http://www.nytimes .com/2016/01/07/opinion/beggars-banquet-in-congress.html?smid=twshare; see also Carl Hulse, Steve Israel of New York, a Top House Democrat, Won't Seek Reelection, N.Y. TIMES (Jan. 5, 2016),_http://www.nytimes.com/2016/01/06/us/politics/steve- 
Congressman Israel also told 60 Minutes: "[a]nd that's the way it went until 2010, when Citizens United was enacted. At that point, everything changed. And I had to increase that to two, three, sometimes four hours a day, depending on what was happening in the schedule." $" 79$ The reaction from some 60 Minutes viewers to this episode was decidedly negative. ${ }^{80}$

Senators cannot avoid the rigors of constant fundraising even though they serve six-year terms. ${ }^{81}$ Indeed, a leaked 2014 midterm election memo to a U.S. Senate candidate raised eyebrows when it suggested that the candidate should spend $80 \%$ of her time fundraising. ${ }^{82}$ Although, the Senate candidate was running for an open seat and had no existing constituency obligations at the time, it is staggering to conceive that eighty percent of the candidate's time should go to fundraising instead of meeting voters, holding public events, debating or formulating policy positions. Also troubling was a claim by former Senate Majority Leader Tom Daschle in 2014 that Senators spend "two-thirds" of their time on fundraising in the last two years of their terms. ${ }^{83}$ And as sitting Senator Chris Murphy explained to Reuters: "It's important for us to expose the ugliness of political fundraising, because people are not going to care about this issue if we continue to pretend like it isn't a big part of our

israel-house-democrat-new-york.html?_r=1 ("I don't think I can spend another day in another call room making another call begging for money," Mr. Israel said in an interview in his congressional office. "I always knew the system was dysfunctional. Now it is beyond broken.").

79 O'Donnell, supra note 19 (quoting Rep. Steve Israel).

80 Evie Salomon, Viewers call out Congress for "Dialing for Dollars," 60 MinUTES (Apr. 27, 2016), https://www.cbsnews.com/news/viewers-call-out-congress-for-dialing-fordollars/ ("'If you think you couldn't hate Congress any more than you already do, turn on 60 Minutes right now,' one viewer tweeted[.]").

81 Bruce Ackerman \& IAn Ayres, Voting with Dollars: A New Paradigm for CAMPAIGn FinAnCE 94-95 (2002) ("To get big gifts politicians not only must solicit big givers. They must do it themselves and cannot afford to delegate the job to professional fundraisers. When speaking privately, they can make all sorts of assurances to big donors without saying anything blatantly criminal like 'give me $\$ 100,000$ and I'll vote for your tax break.' The very fact that Senator X is spending a whole hour in private conversation with the donor attests to the seriousness of his concerns, making such blatant illegalities unnecessary.").

82 Paul Blumenthal, Leaked Memo Tells Senate Candidate to Spend 80 Percent of her Time Raising Money, HuFF. Post (July 28, 2014, 5:41 PM), http://www.huffingtonpost.com /2014/07/28/michelle-nunn-fundraising_n_562 8018. html; Memorandum from Diane Feldman to Michelle Nunn (Dec. 9, 2013) (https://www.scribd.com/fullscreen/235287519 ?access_key=key7XLZhUlmcqs8zb0ft3xs\&allow_share=true\&escape $=$ false \&view_mode $=\mathrm{s}$ croll).

83 Shane Goldmacher, Former Senate Leader Says Senators Spent Two-Thirds of Time Asking for Money Huge campaign needs drive senators up for reelection to put most of their time into raising cash, NAT'L J. (Jan. 16, 2014), https://www.nationaljournal.com/s/63463 /former-senate-leader-says-senators-spent-two-thirds-time-asking-money. 
lives[.]"84

But perhaps equally troubling was a leaked memo from 2013 to freshman House Democrats that suggested they spend between $40 \%$ and $50 \%$ of their time on fundraising. ${ }^{85}$ This practice also appears to be happening on the other side of the aisle, as well. As then-freshman Republican Congressman David Jolly noted after he won a special election, the first order of business was not working on legislation, but rather it was fundraising for the next election: "[w]e sat behind closed doors at one of the party headquarter back rooms in front of a white board where the equation was drawn out. You have six months until the election. Break that down to having to raise $\$ 2$ million in the next six months. And your job, new member of Congress, is to raise $\$ 18,000$ a day." 86

Congressman Jolly also noted that the work schedules for Members of Congress have bowed around fundraising: "You never see a committee working through lunch because those are your fundraising times. And then in between afternoon votes and evening votes, that is when you can see Democrats walking down this street, Republicans walking down that street to spend time on the phone making calls." 87

Congressman Rick Nolan worried in 2016 that the rigors of

84 Andy Sullivan, Insight: In Washington, lawmakers' routines shaped by fundraising, REUTERS (June 12, 2013, 2:46 AM) https://www.reuters.com/article/us-usa-congress-fundra ising-insight/insight-in-washington-lawmakers-routines-shaped-by-fundraising-idUSBRE95 B05520130612 (quoting Senator Murphy).

85 Ryan Grim \& Sabrina Siddiqui, Call Time For Congress Shows How Fundraising Dominates Bleak Work Life, HuFF. Post (Dec. 6, 2017), http://www.huffingtonpost.com/2013 /01/08/call-time-congressional-fundraising-n2427291.html (“A PowerPoint presentation to incoming freshmen by the Democratic Congressional Campaign Committee, obtained by The Huffington Post, lays out the dreary existence awaiting these new back-benchers. The daily schedule prescribed by the Democratic leadership contemplates a nine or 10-hour day while in Washington. Of that, four hours are to be spent in 'call time' and another hour is blocked off for 'strategic outreach,' which includes fundraisers and press work.”); LEE DRUTMAN, THE Bus. of Am. is Lobbying, How Corp. Became Politicized and Pol. Became More CORPORATE 236 (2015) ("Members of Congress spend far too much time fundraising. As the costs of campaigns continue to rise, members of Congress spend more and more hours a day in 'call time.' Increasingly, the main qualification for the job is having a unique personality trait that allows one to withstand several hours a day of begging rich people for money.").

86 O'Donnell, supra note 19 (quoting Rep. David Jolly). For a similar experience from another Florida Congressman, see SCHRAM, supra note 44, at 44 (quoting Rep. Jim Bacchus (D-Florida)) ("Someone like me, in a very marginal seat, begins thinking about reelection a day or so after he is sworn in for a new term-if he wants to get reelected.").

87 O'Donnell, supra note 19 (quoting Rep. David Jolly); see also Rep. Gephardt expressing similar concerns in 2002; see also Hearing on Campaign Finance Reform Before the H. Committee on House Administration, 107th Cong. 4 (May 1, 2002) (statement of Richard Gephardt, U.S. Congressman, Missouri: "Let us decide today that this next election will be conducted differently than in the past; that the focus will be on debating the issues rather than on fundraising schedules. ..") (emphasis added). 
fundraising were getting out of control with freshman Members of Congress who had been encouraged to spend half their time on fundraising and that it could discourage new candidates from trying their hand at politics stating, "both parties have told newly elected members of the Congress that they should spend 30 hours a week in the Republican and Democratic call centers across the street from the Congress, dialing for dollars." ${ }^{" 88}$ Congressman Nolan continued, comparing Congressional call time to professional telemarketing, "30 hours a week, that's a lot of telemarketing. Probably more than most telemarketers do." 89 And Members of Congress that represent districts on the West Coast must juggle call time with travel time. One reported to the L.A. Times that she takes red-eye flights from California to be in DC to arrive in time for call time. ${ }^{90}$ Or as former Governor of Minnesota Arne Carlson and former Member of Congress from Minnesota Gerald Sikorski summed up the impact of excessive fundraising: "The ability for Congress - and our country - to lead on the world stage is now at stake because we have a part-time Congress in a full-time world." 91

\section{What Does The Data About Fundraisers ReVEal?}

As discussed above, there are numerous anecdotes, typically from retiring Members of Congress complaining about the fundraising burden

88 O’Donnell, supra note 19 (quoting Rep. Rick Nolan).

89 O'Donnell, supra note 19 (quoting Rep. Rick Nolan); see also Daniel Hensel, Rep. Joe Schwarz speaks on congressional fundraising, ISSUE ONE (July 27, 2016), https://www.issueone.org/rep-joe-schwarz-speaks-congressional-fundraising/ ("Rep. Joe Schwarz, a former Congressman from Michigan, recently [said in an interview]: 'There's a lot of pressure on especially junior members of Congress . . . to raise money and they're told by ... leadership you're expected to spend a certain amount of time - and really a ridiculously large amount of time - while in Washington at party headquarters, sometimes actually coldcalling people for money. It's been done that way for years."'); see also Brandon Lewis, Why Candidates Hate Fundraising, CAMPAIGNS AND Elections (Oct. 1 2013), https://www.campaignsandelections.com/campaign-insider/why-candidates-hate-fundraising (discussing why it's demeaning and unfulfilling) ("Did little Johnny Candidate ever say, 'I'd like to be a telemarketer or a panhandler when I grow up?' Of course not. However, that is largely what a candidate is vocationally reduced to for months on end despite having developed marketable, specialized skills in his or her career. Fundraising can be tedious, boring and repetitious. It's a creative, right-brainer's nightmare.”).

90 Sarah D. Wire, This Is What It's Like To Be A Cross-Country Flight Away From Your Constituents - And Your Family, L.A. TIMES (Apr. 30, 2018), http://www.latimes.com/politi cs/la-pol-ca-congress-california-fly-home-20180430-story.ht

$\mathrm{ml}$ ("'If you're on a flight on Monday morning, you lose a whole day. I sleep for a few hours, I can start call time around noon, and I at least get maybe four hours of call time in before I have to start my legislative day,' [Rep. Nanette] Barragan said.”).

91 Arne Carlson \& Gerald Sikorski, How 'Dialing For Dollars' Has Perverted Congress, STAR TRIBUNE (May 4, 2016), http://www.startribune.com/how-dialing-for-dollars-hasperverted-congress/378184931/. 
as they leave the political arena. Besides dialing for dollars, lawmakers seeking reelection also need to attend in-person fundraisers. As Thomas E. Mann and Norman J. Ornstein explain, "[p]arty leaders are prolific fund-raisers, as are aspiring leaders ... [b]ecoming a committee chair can depend more on one's fund-raising prowess than one's legislative or policy skills or knowledge." 92

According to Political Party Time, a nonprofit project of the Sunlight Foundation that tracks federal political fundraisers, in the year 2016 there were 1,320 fundraisers, or more than three a day. Of those, 658 were for the Presidential election, and the remainder was for Congressional elections. ${ }^{93}$

Can political scientists discern anything about the impact of inperson fundraisers in the available data? Yes indeed. And it does not bode well. Dr. Eleanor Neff Powell studied the Political Party Time data and compared it to votes in Congress. Dr. Powell's conclusion is that "Members' fundraising for their congressional colleagues impacts both their formal power within the chamber by affecting their rise to both party and committee leadership positions and their informal power within the chamber by increasing their ability to garner the votes of other congressmen to pass their legislative priorities." 94

Dr. Powell also noted the magnitude of the fundraising goals that political parties have set for their members of Congress. ${ }^{95}$ Dr. Powell reported that even pre-Citizens United:

[I]n the 2008 election cycle, rank and file Democratic members were required to contribute $\$ 125,000$ directly from either their personal congressional campaign committee or leadership PAC to the Democratic Congressional Campaign Committee (DCCC) as membership dues. Speaker Pelosi, for example, is expected to directly contribute $\$ 800,000$ to the DCCC and to raise an additional $\$ 25,000,000$, for a total of $\$ 25.8$ million. ${ }^{96}$

Thus, a large part of advancing into Congressional leadership is dependent on fundraising. ${ }^{97}$ As Former Congressman Tim Roemer put it

92 MANn \& ORNSTEIN, supra note 3, at 80.

93 Cent. for Responsive Pol., Political Party Time, http://politicalpartytime.org/ (last visited May 10, 2018).

94 Eleanor Neff Powell, Money and Internal Influence in Congress, SCHOLARS STRATEGY NETWORK 3 (June 10, 2016), http://www.scholarsstrategynetwork.org/sites/default/files/pow ell_money_andinternal_influence_in_.pdf.

95 MANn \& ORnstein, supra note 3, at 80 ("Parties are at the center, not the periphery, of fundraising. They expect members of Congress to raise money for the team through their personal campaign committees and leadership PACs, so that resources can be redistributed from safe to competitive seats.").

96 Powell, supra note 94, at 4.

97 See Josh Keefe, Next House Speaker: McCarthy vs. Scalise Is Battle of Wall Street vs. 
bluntly, "Members are now additionally 'required' to raise money for 'the party' and contribute to pools of funds at the Democratic Congressional Campaign Committee ("DCCC") and the National Republican Campaign Committee ("NRCC"). As a member rises in seniority to committee chair or ranking member, their fundraising responsibilities multiply significantly." $" 98$ In other words, Congress is not a meritocracy where the brightest lawmakers rise to the top. Rather, it is more akin to a boiler room sales operation where the biggest seller receives a set of steak knives and a promotion. As former Congressman Zach Wamp explained, "[i]n Congress, ... [i]f you can raise the most money, you advance." 99 Accordingly, the voting public should worry about the impact of fundraising not just because of the "time suck" problem, but also because it has an impact on who wields power within the House, which in turn determines what legislation moves forward. ${ }^{100}$

\section{No One CAN Multi-Task InCluding Elected OfFicials}

Another reason why fundraising by lawmakers is troubling stems from cognitive science. Because fundraising is not allowed on the grounds of the Capitol, including the buildings where members of the House and Senate keep their offices, members of Congress have to walk to nearby office buildings to engage in fundraising activity. ${ }^{101}$ The argument could be made that these lawmakers might bring their legislative work with them, so as to do legislating and fundraising at the same time. However, this type of multitasking is almost impossible according to new research by psychologists. ${ }^{102}$

Big Oil, NewsWeEK (Apr. 12, 2018, 3:01 PM), http://www.newsweek.com/succeed-ryanmccarthy-relies-wall-street-scalise-oil-883733 (quoting political scientist Matthew Green) (“"The typical member of Congress spends about three to four hours a day dialing for dollars while in D.C. That's mostly for their own re-election,' Green said. 'Speakers, however, are expected to raise money for themselves, for other Republican candidates and for their party. Plus, they travel to fundraisers all over the country."').

98 Tim Roemer, Why Do Congressmen Spend Only Half Their Time Serving Us?, NewsWeEK (July 29, 2015, 11:38 AM), http://www.newsweek.com/why-do-congressmenspend-only-half-their-time-serving-us-357995.

99 Zach Wamp, Being In Congress Is Still All About Fundraising, And Voters Are Tired Of It, WASH. EXAMINER (Mar. 14, 2017, 7:00 PM), https://www.washingtonexamine r.com /being-in-congress-is-still-all-about-fundraising-and-voters-are-tired-of-it.

100 This phenomenon was noted decades earlier. See JefFreY H. BIRNBAUM, SHOwDOwn AT GuCCI GULCH, LAWMAKERS, LOBByisTS, AND THE UNLIKELY TRIUMPH OF TAX REFORM 180 (1988) ("Even politicians with secure seats sought contributions. The more they gave away, the more powerful they could become in Congress.").

101 Bipartisan Campaign Reform Act of 2002, H.R. 2356, § 302, 107th Cong. (2002).

102 Jon Hamilton, Think You're Multitasking? Think Again, NPR (Oct. 2, 2008), http://www.npr.org/templates/ story/story.php?storyId=95256794 (quoting a professor of neuroscience at MIT who said, "You're not paying attention to one or two things simultaneously, but switching between them very rapidly."). 
While humans tend to overestimate their cognitive abilities and wrongly believe they possess the ability to multi-task, cognitive scientists have shown this is not so. ${ }^{103}$ Most human beings actually cannot multitask at all. ${ }^{104}$ As Dr. Paul Atchley, Associate Professor of Cognitive Psychology at the University of Kansas wrote in the Harvard Business Review, "[b]ased on over a half-century of cognitive science and more recent studies on multitasking, we know that multitaskers do less and miss information." 105

Indeed, the idea of multitasking comes from computing, and like computers, the human mind has its limits. Professors of Psychology Daniela M. Kirchberg, Robert A. Roe, and Wendelien Van Eerde have found:

[T] here are limits to what can be done within a certain period. This is even so in the domain of computing from which the concept 'multitasking' originated. . .If there are too many simultaneous processes, programs may jam due to limited storage and the computer may crash. Humans have limited capacities as well and cannot process too many tasks simultaneously (Wickens \& McCarley, 2008). As the human brain struggles to process multiple tasks in parallel, there are negative effects on work results as well as on well-being.

Simply put, there is a limit to humans' attention and ability to process information. ${ }^{107}$ An additional study on multitasking stated, [a]ttention limits the 'sea' of sensory input, enabling individuals to select out and focus on high-priority stimuli, rather than becoming overloaded by the onslaught of the daily

103 Derek Thompson, If Multitasking is Impossible, Why Are Some People So Good at It?, The Atlantic (Nov. 17, 2011), https://www.theatlantic.com/business/archive/2011/11/ifmultitasking-is-impossible-why-are-some-peo ple-so-good-at-it/248648/ (quoting Eyal Ophir, researcher with the Stanford Multitasking study, who said that "[h]umans don't really multitask, we task-switch. We just switch very quickly between tasks, and it feels like we're multitasking.").

104 Travis Bradberry, Multitasking Damages Your Brain and Career, New Studies Suggest, FoRBES (Oct. 8, 2014), https://www.forbes.com/sites/travisbradberry/2014/10/08/m ultitasking-damages-your-brain-and-career-new-studies-suggest/\#2f64375e56ee (citing a study at Stanford showing that "multitaskers" who think they are good at multitasking and do it often are actually worse at multitasking than those who focus on one task at a time. The multitaskers were slower at switching tasks because they could not filter out irrelevant information or organize their thoughts).

105 Paul Atchley, You Can't Multitask, So Stop Trying, HARV. Bus. Rev. (Dec. 21, 2010), https://hbr. org/2010/12/you-cant-multi-task-so-stop-tr.

106 Daniela M. Kirchberg, Robert A. Roe, \& Wendelien Van Eerde, Polychronicity and Multitasking: A Diary Study at Work, 28 HuMAN PERFORMANCE 112, 131 (2015) (discussing the practical implications).

107 Steve Lohr, A Warning on the Limits of Multitasking, N.Y. TIMES, (Mar. 25, 2007), http://www.nytimes.com/2007/03/25/business/worldbusiness/25iht-multi.1.5014965.html?m cubz $=2$ ("'But a core limitation is an inability to concentrate on two things at once,' said René Marois, a neuroscientist and director of the Human Information Processing Laboratory at Vanderbilt University."). 
stimulation. Because people possess a limited amount of attentional resources, it is difficult to attend to multiple stimuli in the environment at once[.] ${ }^{108}$

Even common actions that most people do simultaneously are, in actuality, abject failures under closer scrutiny. ${ }^{109}$ For example, driving while talking on the phone is not something that most drivers can actually do safely.

[Dr. David] Strayer .... and his colleagues had demonstrated that drivers using cell phones-even hands-free deviceswere at just as high a risk of accidents as intoxicated ones. Reaction time slowed, attention decreased to the point where they'd miss more than half the things they'd otherwise seea billboard or a child by the road, it mattered not."

This inability to multitask has even been found among police officers, who struggle with driving while also processing auditory information. As researchers found, "[one] police officer missed incoming radio messages because he preferred to prioritize the driving task while the other police officer committed traffic violations as a result of paying more attention to the radio messages."111

And for those who argue that lawmakers can immediately start work legislating once they return to Capitol Hill from call time off campus, there is more bad news. ${ }^{112}$ Cognitive scientists also find that when switching between disparate tasks, time is lost when the thinker returns to the primary task. ${ }^{113}$ As Professor Atchley explained, "[i]t takes time

108 Tova Miller, Sufen Chen, Wei Wei Lee, \& Elyse S. Sussman, Multitasking: Effects of Processing Multiple Auditory Feature Patterns, 52 Psychophysiology 1140 (Sept. 2015) (introducing the study and discussing the theories regarding multitasking).

109 Lohr, supra note 107 ("'Multitasking is going to slow you down, increasing the chances of mistakes,' said David Mayer, a cognitive scientist and director of the Brain, Cognition and Action Laboratory at the University of Michigan.”).

110 Maria Konnikova, Multitask Masters, THE NEw YORKER (May 7, 2014), http://www. new yorker.com/ science/maria-konnikova/multitask-masters.

111 Reinier J. Jansen, Rene van Egmond, \& Huib de Ridder, Task Prioritization in DualTasking: Instructions Versus Preferences, 11 PLOS ONE 1, 2 (July 8, 2016); but see Harold Pashler, Sean H. K. Kang, \& Renita Y. Ip, Does Multitasking Impair Studying? Depends on Timing, 27 APPlied Cognitive PsyChOL. 593, 597 (Mar. 18, 2013) (discussing the results generally and "Multitasking produced a marked and substantial reduction in information acquired from educational materials when the materials were presented in spoken form and played without waiting for the learner. On the other hand, when the learner read the materials at his or her own pace, there was no sizable or significant reduction in information acquired.").

112 Christine Rosen, The Myth of Multitasking, The New Atlantis: A J. of TeCH. \& Soc. (Spring 2008), (http://www.thenewatlantis.com/publications/the-myth-o-multitasking) ("One study by researchers at the University of California at Irvine monitored interruptions among office workers; they found that workers took an average of twenty-five minutes to recover from interruptions such as phone calls or answering e-mail and return to their original task.").

113 Lohr, supra note 107 ("In a recent study, a group of Microsoft workers took, on average, 15 minutes to return to serious mental tasks, like writing reports or computer code, after responding to incoming e-mail or instant messages. They strayed off to reply to other 
(an average of 15 minutes) to re-orient to a primary task after a distraction .... Efficiency can drop by as much as $40 \%$. Long-term memory suffers and creativity-a skill associated with keeping in mind multiple, less common, associations - is reduced."114

Moreover, getting interrupted from a primary task during work can intensify the problem of a time famine for the worker. The work of Quintus R. Jett and Jennifer M. George has found that time pressure is likely to lead to stress, ${ }^{115}$ noting "[a]dditional negative effects related to time pressure may include heightened feelings of stress and anxiety, as the person being interrupted recognizes that less time is available and that he or she may be falling short in reaching task milestones."116 Other researchers have similarly shown that "[n]otwithstanding the commonly assumed positive effects associated with multitasking, our study shows that multitasking goes together with lower self-rated performance and with lower affective well-being, particularly when the preference for multitasking is low."117 If the average person cannot do two tasks at the same time, expecting someone to legislate and talk on the phone at the same time seems a tall—if not impossible-order.

\section{WHAT HAPPENS WHEN INCUMBENT CANDIDATES RUN OUT OF TIME: POLICY AND FUNDRAISING GET OUTSOURCED}

Where do elected officials turn to help with soliciting campaign money once they run out of time? It is not the great body of the people of the United States that James Madison referred to in Federalist No.

\footnotetext{
messages or browse news, sports or entertainment Web sites.").

114 Atchley, supra note 105.

115 Kirchberg, supra note 106, at 133 (concluding the results: "The high demands on ... cognitive resources needed to multitask on a daily basis may lead to burnout symptoms, reduced job satisfaction, and lowered commitment, and this may result in worsened performance.").

116 Quintus R. Jett \& Jennifer M. George, Work Interrupted: A Closer Look at The Role of Interruptions in Organizational Life, 28 ACAD. OF MGMT. REV. 494, 496 (2003) (discussing interruptions).

117 Kirchberg, supra note 106, at 129-30; see also Brandon Ralph, David Thomson, James Cheyne, \& Daniel Smilek, Media Multitasking and Failures of Attention in Everyday Life, 78 Psychol. RES. 661, 667 (Sept., 2014) ("media multitasking might atrophy endogenous attentional control, which ultimately leads to a subjective increase in attention related errors in everyday life.").
} 
57. ${ }^{118}$ Often the answer is lobbyists. ${ }^{119}$ Given the size of the administrative state, there is a lot to lobby about. ${ }^{120}$ As Thomas E. Mann and Norman J. Ornstein describe:

[i]n a city [D.C.] where much of the business is about divvying up over $\$ 3$ trillion in federal spending and carving out tax breaks from over $\$ 2$ trillion in revenues, the money spent on influencing those decisions has mushroomed, and the money that lobbyists and their associates make has become almost mind-boggling. ${ }^{121}$

Lobbyists are both potential sources of campaign checks as well as potential bundlers of donations from others, including their lobbying clients. Furthermore, many lobbyists organize in-person fundraisers on behalf of Members of Congress. ${ }^{122}$

Regarding the campaign finance system, Leon Panetta (who would later serve as the Director of the Central Intelligence Agency and Secretary of Defense under President Obama) stated:

[1] egalized bribery has become part of the culture of how this place [D.C.] operates. Today's members of the House and Senate rarely legislate; they basically follow the money .... . They're spending more and more time dialing for dollars .... The only place they have to turn is to the lobbyists. Members have a whole list of names in their pockets at all times, and they just keep dialing. It has become an addiction that they can't break.

118 Laurence H. Tribe, Dividing Citizens United: The Case v. The Controversy, 30(2) Const. Comment. 463, 479 (Summer 2015) (quoting James Madison's Federalist 57. "Who are to be the electors of the federal representatives? Not the rich, more than the poor; not the learned, more than the ignorant; not the haughty heirs of distinguished names, more than the humble sons of obscure and unpropitious fortune. The electors are to be the great body of the people of the United States.").

119 LESSIG, supra note 26, at 113 ("As one lobbyist put it expressly, 'I spend a huge among of my time fundraising ... A huge amount.' That behavior has been confirmed to me by countless others, not so eager to be on the record.").

120 William Greider, Who Will Tell the People The Betrayal of American DEMOCRACY 107 (1993) ("The explosion of modern regulation, more than anything else, is what brought the money to Washington and transformed the capital from a sleepy small town to a glamorous power center. During the 1930s, Roosevelt's New Deal created 42 major regulatory agencies and programs. Most of these involved economic regulation of specific sectors (airlines, broadcasting, oil and agricultural production and others), arrangements usually created in cooperation with the affected industries. During the 1960s, 53 regulatory programs were enacted, as consumer issues and environmental protection gained political momentum. From 1970 to 1980,130 major regulatory laws were enacted. That is what brought the Fortune 500 to Washington, along with the tens of thousands of lawyers.").

121 MANN \& ORNSTEIN, supra note 3, at 68.

122 Robert G. Kaiser, So Damn Much Money The Triumph of Lobbying And the CORRosion OF AMERICAN GOVERnMENT 292 (2009) ("Employees of the [Cassidy] firm were never instructed to make specific contributions but they knew that they were expected to pony up. 'It was clearly understood that we were to give about half our annual bonus to politicians,' Smith recalled.").

123 Id. at 19 (quoting Leon Panetta). 
Or as Jeffrey H. Birnbaum explained colorfully in his book on lobbying: "Washington was a virtual money machine, and lobbyists provided much of the fuel. It was if there were a nightly sale, and the members of Congress were the merchandise." 124

Fundraising has become an exhausting endeavor for both lawmakers and lobbyists. Lee Drutman reported a lobbyist complaining that, "on any given day I'll get 25 faxed invitations to Washington-based fundraisers." "25 John B. Judis noted in his book that "Thomas Boggs, one of Washington's most successful lobbyists, became know for hosting events for as many as 125 politicians during each election season." 126 Robert G. Kaiser reported in his book on money in politics,

[t] he people who worked for [the lobbyist firm] Cassidy understood that giving [political donations] was part of their job ... Geoff Gonella, who worked at the firm from 1992 to 2002, said, 'Cassidy realized that the way to get things done .... was to be a huge financial resource for members of Congress.'

The fundraising expectations for lobbyists has only increased thanks to a 2014 Supreme Court case called McCutcheon which invalidated the long-standing two-year aggregate limit on individual donations in the Federal Election Campaign Act of 1971 ("FECA 1971") as amended by the Bipartisan Campaign Reform Act of 2002 ("BCRA"). ${ }^{128}$ A lobbyist told the press after McCutcheon, "I'm horrified, planning to de-list my phone number and destroy my email address .... What I was really hoping for is a ban on lobbyists making contributions entirely."129

Many lobbyists are also lawyers. And the American Bar

124 BIRNBAUM, supra note 100 , at 179.

125 Lee Drutman, The Bus. of Am. is Lobbying, How Corp. Became Politicized and Politics BeCAme More Corporate 95 (2015); see also JeFFrey H. Birnbaum, Showdown AT GuCCI Gulch, LAWMAKERS, LOBbyists, AND THE UNLIKELY TRIUMPH OF TAX REFORM xii (1988) (Introduction by Albert Hunt) ("Most politicians spend enormous time raising these [campaign] funds; rarely does a night go by in Washington without a political fundraiser populated chiefly by special interests.").

126 John B. Judis, The Paradox of Am. Democracy: Elites, Special Interests, and The Betrayal of Public Trust 133-134 (2000).

127 KAISER, supra note 122, at 292; see also SCHRAM, supra note 44, at 98 (quoting Rep. Tim Penny (D-Minnesota)) ("Look at Cassidy and Associates if you want a classic example of how it works in small ways. This is a lobbying firm that also goes out of its way to also help raise money, hold fund-raisers for individuals [in Congress]. Not so much their own money, but they help corral other contributions.").

128 Zephyr Teachout, The Supreme Court's McCutcheon V. FEC Ruling Leaves A Campaign Finance Void, WASH. POST. (Apr. 3, 2014), https://www.washingtonpost.com/opin ions/the-supreme-courts-mccutcheon-v-fec-ruling-leaves-a-campaign-finance-void/2014/04/ 03/b20a7d38-ba93-11e3-9a05-c739f29ccb08story.html?utm_term=. fbe0223c512b.

129 Anna Palmer \& Tarini Parti, Big Donors Fear Shakedown, Politico (Apr. 2, 2014), http://www.politico.com/story/2014/04/supreme-court-campaign-finance-donations-mc-cut cheon-105320\#ixzz3s eZZ9o8X. 
Association ("ABA") has taken notice of how these lobbyist lawyers have been interacting in our political system. The ABA's Task Force on Federal Lobbying Laws reported with some dismay:

[T] he multiplier effect of a lobbyists' participation in fundraising for a member's campaign (or the member's leadership PAC) can be quite substantial, and the Task Force believes that this activity should be substantially curtailed .... [A] self-reinforcing cycle of mutual financial dependency has become a deeply troubling source of corruption in our government.

But the reason lobbyists are frequently donors to Members is summed up by an admission of current OMB Director Mick Mulvaney, who was a Member of Congress for six years. As reported in the press Mr. Mulvaney stated:

We had a hierarchy in my office, in Congress. If you were a lobbyist who never gave us money, I didn't talk to you," Mulvaney said, according to a transcript of his speech to the American Bankers Association provided by the CFPB. "If you were a lobbyist who gave us money, I might talk to you. If you came from back home and sat in my lobby, I talk to you without exception, regardless of the financial contributions," he continued.

In other words, as a Congressman, Mr. Mulvaney and his staff barred access for lobbyists who were not political donors to his campaigns. ${ }^{132}$

If they are not turning to lobbyists who have business pending before the government, federal candidates will raise political funds from wealthy donors. ${ }^{133}$ For instance, former Secretary of State, Hillary Clinton was

130 LESSIG, supra note 26, at 119 (quoting ABA report from the Task Force on Federal Lobbying Laws).

131 Kate Ackley, Mulvaney Backlash May Drive Political Money Changes, Roll Call (Apr. 26, 2018), https://www.rollcall.com/news/policy/mulvaney-backlash-political-money; see also Meredith McGehee, Time for Washington to end the tradition of 'pay to play' politics, THE HiLl (Apr. 27, 2018, 12:00 PM), http://thehill.com/opinion/finance/385193-time-forwashington-to-end-the-tradition-of-pay-to-play-politics.

132 Caitlin Byrd, Former South Carolina GOP congressman Mick Mulvaney admits his access was tied to donors, CHARLESTON POST \& COURIER (Apr. 25, 2018), https://www.postan dcourier.com/politics/former-south-carolina-gop-congressman-mick-mulvaney-admits-his-a ccess/article_0e335b3e-4893-11e8-87f2-a3212f3144d1.html (“'It sounds like Mick is swimming in the swamp more than draining the swamp, and it's a problem,' said Bob Inglis, another former South Carolina congressman.").

133 Tribe, supra note 118, at 481 ("[We are] in the era of what many have called a 'great divergence[]' ... over the past four decades America has witnessed ever-growing (and too often racially skewed) gaps between rich and poor: in income, wealth, health, educational outcomes, and even in family stability. As the lived experiences of the wealthy and the poor diverge, it becomes increasingly significant that the political system is more responsive-and widely understood to be more responsive - to the preferences of one group than to those of the other."); see also Sarah C. Haan, The CEO and the Hydraulics of Campaign Finance Deregulation, 109 NORTHWESTERN U. LAW R. 269, 272 (2015) (“Ordinary Americans believe 
an avid fundraiser in her second attempt to run for president. Prior to the 2016 presidential election, in August, "Mrs. Clinton raked in roughly $\$ 50$ million at 22 fund-raising events, averaging around $\$ 150,000$ an hour, according to a New York Times tally ... she fielded hundreds of questions from the ultrarich in places like the Hamptons, Martha's Vineyard, Beverly Hills and Silicon Valley." "134 In contrast to President Obama, who had a day job at the time he was campaigning - being PresidentSecretary Clinton did not have a government job while campaigning, and thus her dedication to fundraising did not take away from governing responsibilities. Secretary Clinton was seemingly, day after day, surrounded by some of the wealthiest Americans at fundraisers and events. Members of Congress frequently take a similar approach. As Nick Penniman and Wendell Potter described, "[t]he hard money chase marinates our elected representatives in the mind-sets of the wealthy and special interests - and takes them away from doing the job we voters pay them to do." 135

What do the biggest donors get in return for the campaign contributions and expenditures? This is a matter of great debate and dispute. ${ }^{136}$ Martin Gilens argues, based on his empirical studies, "[ $\left.t\right]$ he American government does respond to the public's preferences, but that responsiveness is strongly tilted toward the most affluent citizens. Indeed, under most circumstances, the preferences of the vast majority of Americans appear to have essentially no impact on which policies the

they have lost the ability to command the attention of candidates and elected officials because they cannot compete with the significant election-related spending of the 'donor class.' This is an elite group of wealthy individuals - according to the Sunlight Foundation, 31,385 people-who in 2012 donated more than one-quarter of the money spent on federal elections.").

134 Amy Chozick \& Jonathan Martin, Where Has Hillary Clinton Been? Ask the Ultrarich, N.Y. TimES (Sept. 3, 2016), http://www.nytimes.com/2016/09/04/us/politics/hillary-clintonfundraising.html?_r=0.

135 Nick Penniman \& Wendell Potter, Citizens United is only $15 \%$ of the political cash problem, L.A. TimES (Mar. 8, 2016), http://www.latimes.com/opinion/op-ed/la-oe-pennimanpotter-political-campaign-finance-reform-20160308-story.html.

136 Michelle C. Gabriel, McConnell v. Federal Election Commission: The Problem of Eradicating Campaign Finance Corruption, 12 Rich. J.L. \& PuB. InT. 1, 13 (2008) (New York City Bar Association studied contributions and found that large contributions most often resulted in specific wording in a bill, making a certain bill a priority, or allowing the donor an opportunity to make his case rather than outright buying the vote); but see Bradley A. Smith, Faulty Assumptions and Undemocratic Consequences of Campaign Finance Reform, 105 YaLe L.J. 1049, 1068 (1996) ("A substantial majority of those who have studied voting patterns on a systematic basis agree that campaign contributions affect very few votes in the legislature."); Lynda W. Powell, The Influence of Campaign Contributions on the Legislative Process, 9 Duke J. Const. L. \& Pub. POL'Y 75, 100 (2014) (claiming that donor influence on actual roll-call votes is negligible (or at least hard to pin down), but there is certainly influence on softer functions upstream in the legislative process like a bill having a higher priority in committee or the bill gets killed quietly.). 
government does or doesn't adopt." ${ }^{\prime 137}$ Perhaps this is why the American public holds Congress in such low esteem. ${ }^{138}$

The biggest donors are unquestionably shaping the legislative agenda, especially if they have been reliable sources of funding over the decades. ${ }^{139}$ Big donors, those who can and do give hundreds of thousands of dollars far outstrip the smaller donors at the $\$ 1,000$ or less mark. ${ }^{140}$ For instance, in "Dark Money," author Jane Mayer describes how the Koch Brothers, long-term mega-donors, has influenced and shaped Congressional agendas. As Mayer puts it, "the Kochs had fulfilled Charles's 1981 ambition not just to support elected politicians, whom he regarded as mere 'actors playing out a script,' but to 'supply the themes and words for the scripts.", 141 Mayer went on, "[b]y 2015, their [the Koch Brothers'] antigovernment lead was followed by much of Congress. Addressing global warming was out of the question. Although economic inequality had reached record levels, raising taxes on the runaway rich and closing special loopholes that advantages only them were also nonstarters." "142 Professor Jacob Hacker reported similar successes by the Kochs:

Indeed, for most organized interests, spending on elections is just the training season; the real games begin once elected officials start governing. David Koch put it bluntly: 'Our main interest is not participating in campaigns . . . . Our main interest is in policy.' This from a man who, combined with his brother and the political network he leads, spent more in the 2012 election cycle than the entire campaign of John

137 Adam Lioz \& Karen Shanton, Moving from Big Money Dominance in the 2014 Midterms to a Small Donor Democracy, 9 (2015) (quoting Martin Gilens), http://www.uspirg .org/sites/pirg/files/reports/TheMoneyChase-Report_0.pdf.

138 Domenico Montanaro, Here's Just How Little Confidence Americans Have In Political Institutions, NPR (Jan. 17, 2018, 5:00 AM ET) https://www.npr.org/2018/01/17 1578422668/heres-just-how-little-confidence-americans-hav

e-in-political-institutions ("The American public has the least confidence in Congress, the body tasked with making laws that can affect every person in the country. Just 8 percent of people have a great deal of confidence in the institution.").

139 Thomas Stratmann, The Market for Congressional Votes: Is Timing of Contributions Everything?, 41 J.L. \& ECON. 85, 110 (1998) ("PACs use these funds to influence campaigns and legislative events.").

140 Blair Bowie \& Adam Lioz, PIRG and Demos, Distorted Democracy: PostELECTION SPENDING ANALYSIS 1 (2012), http://uspirg.org/sites/pirg/files/reports/post\%20elec tion\%20megaphones\%20FINAL.pdf ("[J]ust 61 large donors to Super PACs giving an average of $\$ 4.7$ million each matched the $\$ 285.2$ million in grassroots contributions from more than $1,425,500$ small donors to the major party presidential candidates.").

141 MAYER, supra note 66, at 374.

142 MAYER, supra note 66, at 374; see also Jacob S. Hacker \& Nathan Loewenthiel, How Big Money Corrupts the Economy, 27 DEMOCRACY J. 32, 33-34 (2013), http://democracy journal.org/magazine/27/how-big-money-corrupts-the-economy/ ("Six in ten of the richest 0.1 percent of Americans are corporate or financial executives. The Koch brothers, for example, are both huge individual donors and leaders of an industry juggernaut."). 
McCain did in 2008. ${ }^{143}$

And the Koch Brothers have continued pushing policy in 2017. ${ }^{144}$

What the Koch Brothers did on an enormous scale, other donors did on a smaller scale. At least one Senator admitted that political donors had the ability to influence the way Senators conducted their legislative work. Senator Wyche Folwer stated:

I was on the Ways and Means Committee for six years. And every single interest that comes to you has got a special private interest where they are seeking to get subsidized, through the tax code ... I am sure that on many occasionsI'm not proud of it - I made the choice that I needed this big corporate client and therefore I voted for, or sponsored, its provision, even though I did not think it was in the was best interest of the country or the economy.

Congressman Vin Weber admitted to similar activity when he was in Congress. Congressman Weber stated: "all of us, me included, are guilty of this: [i]f the company or interest group is (a) supportive of you and (b) vitally concerned about an issue that (c) nobody else in your district knows about or ever will know about, then the political calculus is very simple." "Congressman Levine found the impact of money in politics to be even broader stating, "[o]n the tax side, the appropriations side, the subsidy side and the expenditure side, decisions are clearly weighted and influenced... by who had contributed to the candidates."147 Or as Senator John McCain once summed up, "it would be hard to find much legislation enacted by any Congress that did not contain one or more obscure provision that served no legitimate national or even local interest, but which was intended only as a reward for a generous campaign supporter."148 As recently as 2016, Congressman Walter Jones indicated, "[t]his place has not done anything since McCain-Feingold in the area of campaign finance reform. We've done nothing. Policy is controlled by special interests. Policy should be

143 Hacker \& Loewenthiel, supra note 142, at 35.

144 Steve Peoples, Donor to GOP: No Cash Until Action on Health Care, Taxes, U.S. News (June 26, 2017, 11:32 AM), https://www.usnews.com/news/politics/articles/2017-06$26 /$ koch-urgency-conservative-network-fears-closing -window ("Indeed, there was a sense of frustration and urgency inside the private receptions and closed-door briefings at the Koch brothers' donor retreat this weekend in Colorado Springs, where the billionaire conservatives and their chief lieutenants warned of a rapidly shrinking window to push their agenda through Congress and get legislation to President Donald Trump to sign into law.").

145 Schram, supra note 44, at 3 (quoting Sen. Wyche Folwer (D-Georgia)).

146 Schram, supra note 44, at 4 (quoting Rep. Vin Weber (R-Minnesota)).

147 Schram, supra note 44, at 89 (quoting Rep. Mel Levine (D-California)).

148 Monica Youn, The Fair Elections Now Act: A Comprehensive Response to Citizens United, BRENNAN CENT. FOR JUST. 10 (2011), https://www.brennancenter.org/analysis/fairelections-now-act-comprehensive-response-citizens-united (quoting Senator John McCain (R-Arizona)). 
controlled by the people."149

Of course, every poor policy decision cannot be traced definitively to the role of money in politics. But it does seem to lie at the heart of many disastrous policies from the S\&L bailout to the more recent TARP bailout. ${ }^{150}$ Ms. Alyssa Katz notes that one explanation for the housing policies that led to the 2008 financial collapse of the U.S. economy is traceable to political spending by real estate interests in Congressional races. According to Ms. Katz:

[r]eal estate interests constitute the most generous lobby in Washington. Four out of the ten biggest political action committees contributing to Congress build, sell, or fund homes. The finance and real estate industries together spent nearly $\$ 2$ billion lobbying Congress in the decade that began in 1998 (with almost \$300 million of that in 2007 alone). Since 1990 they've given nearly as much in congressional campaign contributions. The real estate industry's lobbyists have helped create a climate in which the very possibility of government policies that might set reasonable limits on lending have been rendered unthinkable.

Thus, fundraising can impact what bills move in Congress. ${ }^{152}$

Donors often want access to the candidate after the election. ${ }^{153}$ As Congressman Romano Mazzoli said, "[p]eople who contribute get the ear of the member and the ear of the staff. They have the access - and access is it. Access is power. Access is clout. That's how this thing works."154 The interaction between fundraiser and funder can become quite

149 Michael Beckel, Meet the GOP Congressman Who Wants to Overturn 'Citizens United': Walter Jones Says Fundraising Has 'Gotten Out of Hand' in Washington, CENT. FOR PUB. InTEGRITY (Jan. 21, 2016, 3:00 AM), https://www.publicintegrity.org/2016/01/21/19154 /meet-gop-congressman-who-wants-overturn-citizens-united.

150 SABATO \& Simpson, supra note 25, at 8 (referring to the Keating Five Scandal) ("evidence abounds that oversight of the nation's financial system was corrupted by legal campaign contributions."); see also RICHARD A. POSNER, THE CRISIS OF CAPITALIST DEMOCRACY 169-70 (2010) ("The government had created that environment [of lax financial regulation], albeit under pressure from the finance industry. Moneyed interest groups, dispensing the quasi-bribes known as campaign donations, exert a powerful influence on American government.").

151 Alyssa Katz, Our Lot How Real Estate Came to Own Us 225 (2009); see also Bethany McLean \& Joe Nocera, All the Devils Are Here: the HidDen History of the FINANCIAL CRISIS 44 (2011) ("Fannie Mae also funneled money to politicians. In addition to campaign contributions, Fannie set up a foundation that made contributions to politically useful causes .... It made heavy donations to, among others, the nonprofit arms of the Congressional Black Caucus and the Congressional Hispanic Caucus.").

152 SChrAM, supra note 44, at 21 (quoting Rep. Don Edwards (D-California) ("It is a concern to the institution because you are financed largely not by yourself, not by friends, but by people with an interest in legislation.").

153 Weiss, supra note 24 (responding to the question, "[a]s fundraisers, what do you see as your major challenges approaching the 2012 campaign cycle? . . Kimberly Scott [said] . . donors are motivated by three basic things: the candidate, the issue, or the access.").

154 SCHRAM, supra note 44, at 4 (quoting Rep. Romano Mazzoli). 
transactional. Responding to the question, "[a]re you finding that it is more difficult to reach out to larger donors? Are they more inundated with fundraising solicitations?" Steve Linder a partner at the Sterling Corporation, a Michigan based Republican consulting firm said,

[o]ne point that I don't want to get lost is we're all talking about raising money at, sort of, point of sale. One factor that plays into whether or not we're going to continue to raise large dollars from known donors is the care and feeding that they get. And one thing that we are finding is a lot of donors, especially those that have weathered a very bad economy for several years and feel a bit beleaguered, are responding to those that communicated with them, that took care of them, that kept them informed and made them feel that they weren't just a check, but that they were a valued customer.

In late 2017, Congress happened to be in the middle of a once in a generation attempt to overhaul the American tax code. ${ }^{156}$ This was on the heels of a failure by Congress to repeal the Affordable Care Act, which would have included massive tax cuts for the wealthy. ${ }^{157}$ The failure to repeal the Affordable Care Act was followed by a drop in donations to Senate Republicans. ${ }^{158}$

One motivator of this effort to revise the tax code was the desire by wealthy political donors for personal tax cut for themselves, their families and their businesses. ${ }^{159}$ And both donors and certain lawmakers were surprisingly confessional about the fact that big donors were demanding these tax cuts. ${ }^{160}$ For example on the donor side, the press reported quotes

155 Weiss, supra note 24.

156 Thomas Kaplan \& Alan Rappeport, House Passes Tax Bill, as Does Senate Panel, N.Y. Times (Nov. 16, 2017), https://www.nytimes.com/2017/11/16/us/politics/house-taxoverhaul-bill.html.

157 Carl Hulse, Behind New Obamacare Repeal Vote: 'Furious' G.O.P. Donors, N.Y. TIMES (Sept. 22, 2017), https://www.nytimes.com/2017/09/22/us/politics/republican-donorsobamacare-repeal.html ("Campaign fund-raising was drying up, [Senator Cory Gardner] said, because of widespread disappointment among donors over the inability of the Republican Senate to repeal the Affordable Care Act or do much of anything else.").

158 Geoff West, Koch Network's Failing Investment In ACA Repeal, HuFF. Post (Oct. 10, 2017, 9:40 AM), https://www.huffingtonpost.com/entry/koch-networks-failing-investmentin-acarepeal_us_59dcccb3e4b0a1bb90b8 $30 f 6$ ("Contributions reported by the RNSC have plummeted since March, specifically after the Senate's failed repeal vote in July, according to FEC filings.").

159 Dere Thompson, Why the GOP's Dream of Tax Reform Is (Probably) Doomed, THE ATLANTIC (Nov. 9, 2017), https://www.theatlantic.com/business/archive/2017/11/gop-taxcut/545450/ ("By eliminating the estate tax, it would benefit heirs of large estates, even if they don't work a day in their life.").

160 Russ Choma, Republicans Say They've Got to Act on Tax Reform-or Donors Might Get Mad, Mother Jones (Nov. 10, 2017, 11:14 AM), http://www.motherjones.com/politics/2 017/11/republicans-say-theyve-got-to-act-on-tax-reform-or-donors-might-get-mad/ ("Everyone knows politicians pay excessive attention to the demands of their campaign donors. But if you're a politician, you're not supposed to actually say that publicly.'); Paul 
like these:

Doug Deason, a well-known conservative donor from Texas, announced that 'the Dallas piggy bank' for Republican politicians was closed until GOP lawmakers started delivering. He had already refused two congressional Republicans who had asked him to hold fundraisers. 'Get Obamacare repealed and replaced, get tax reform passed,' Deason said. 'You control the Senate. You control the House. You have the presidency. There's no reason you can't get this done. Get it done and we'll open it [fundraising] back up.'

Earlier in the year, the Koch network made its position on tax reform clear: "IIf they don't make good on these promises [for tax reform] . . . there are going to be consequences, and quite frankly there should be,' said Sean Lansing, chief operating officer for the Koch network's political arm, Americans For Prosperity." 162 Fundraisers for Republican Super PACs were also clear: "“[Donors] would be mortified if we didn't live up to what we've committed to on tax reform,' Steven Law, the head of Senate Conservatives Fund, a super PAC affiliated with Senate Majority Leader Mitch McConnell (R-Ky.), told the New York Post."163

And from Members of Congress the public heard surprisingly candid quotes like this: “"Donors are furious,' one person knowledgeable about the private meeting quoted [Senator] Gardner as saying. 'We haven't kept our promise." 164 Additionally "Senator Lindsey Graham (R-S.C.) said GOP donors will quit giving to Republicans if Congress does not pass tax reform." 165 Meanwhile in the House, Congressman

Blumenthal, Republicans Admit That CEOs And Donors Really Need The Tax Cut Bill To Pass-Or Else, HuFF. Post (Nov. 9, 2017, 1:57 PM), https://www.huffingtonpost.com/entry /gary-cohn-tax-cut-ceos-donors_us_5a049571e4b 0f76b05c4249e ("It isn't often that politicians admit that their failure to pass legislation will impact their ability to collect money for their campaigns. They usually try to avoid an appearance that campaign contributions are linked to specific legislation."); Geoff West, Koch Network's Failing Investment In ACA Repeal, HuFf. Post (Oct. 10, 2017, 9:40 AM), https://www.huffingtonpost.com/entry/kochnetworks-failing-investment-in-acarepeal_us_59 dcccb3e4b 0a1bb90b830f6 ("Repealing health care isn't the only priority of conservative dark money, however, and Republicans have turned quickly to a savoir-revising the tax code - with the eyes of deep-pocketed donors waiting and watching.").

161 Russ Choma, Republicans Say They've Got to Act on Tax Reform-or Donors Might Get Mad, Mother JONES (Nov. 10, 2017, 11:14 AM), http://www.motherjones.com /politics /2017/11/republicans-say-theyve-got-to-act-on-tax-reform-or-donors-might-get-mad/.

162 Peoples, supra note 144.

163 Blumenthal, supra note 160.

164 Carl Hulse, Behind New Obamacare Repeal Vote: 'Furious' G.O.P. Donors, N.Y. Times (Sept. 22, 2017), https://www.nytimes.com/2017/09/22/us/politics/republican-donorsobamacare-repeal.html.

165 Rebecca Savransky, Graham: 'Financial Contributions Will Stop' If GOP Doesn't Pass Tax Reform, THE HiLl (Nov. 9, 2017, 11:32 AM), http://thehill.com/policy/finance/3596 06-graham-financial-contributions-will-stop-if-gop-doesnt-pass-tax-reform. 
Chris Collins when asked by a reporter if donors are happy with the taxreform proposal said this: "My donors are basically saying, "Get it done or don't ever call me again."

This is all a bit galling since the tax cuts for the rich in the House version of the bill are paid for by raising the taxes on individuals who earn between $\$ 10,000-\$ 75,000$ a year; and by lowering or eliminating tax deductions used by the middle class, such as, mortgage interest deduction, local tax deductions, medical expense deductions and school supplies deductions for teachers. Even White House advisers admitted that the individuals who would be most pleased by the tax bill are CEOs and the Business Roundtable. ${ }^{167}$ But even if voters take out their anger on politicians who raise their taxes, politicians must have calculated that it was more important to first keep political donors happy and then try to win over voters with campaign money.

\section{A. Reforms in Light of the Problem of Dwindling Candidate Time}

Polling in recent years reveals that there is an appetite for campaign finance reform among the American public. ${ }^{168}$ For instance, in a Washington Post poll sixty-five percent pointed to money in politics as "causing dysfunction in the U.S. political system." 169 And in 2018 Pew found seventy-seven percent of Americans in favor of campaign finance reform. ${ }^{170}$ There are a few solutions that could help solve the "time suck"

166 Cristina Marcos, GOP Lawmaker: Donors are pushing me to get tax reform done, THE HILL (Nov. 10, 2017, 11:23 AM), http://thehill.com/homenews/house/359110-gop-lawmaker -donors-are-pushing-me-to-get-tax-reform-done; see also Peoples, supra note 144 ("It's the same for an overhaul of the tax code, [Congressman] Brat said: 'We don't get taxes through, we're all going home. Pack the bags.").

167 Blumenthal, supra note 160 ("“The most excited group out there are big CEOs, about our tax plan,' Gary Cohn, the leading White House economic adviser and former chief operating officer at Goldman Sachs, said in an interview with CNBC on Thursday."); Sylvan Lane, Cohn: CEOs Are The 'Most Excited Group' About GOP Tax Plan, THE HILl (Nov. 9, 2017, 9:51 AM), http://thehill.com/policy/finance/359573-cohn-ceos-are-the-most-excitedabout-gop-tax-plan ("“So, our biggest supporters are really the Business Roundtable,' said Cohn, referring to the powerful group of major U.S. executives that's thrown millions of dollars behind ads supporting the GOP tax bill.”).

168 Majority of Americans Support Campaign Finance Reform Ipsos Poll on behalf of the Center for Public Integrity, IPSOS (Aug. 31, 2017), https://www.ipsos.com/en-us/newspolls/center-for-public-integrity-2017-08-31.

169 John Wagner \& Scott Clement, 'It's Just Messed Up': Most Think Political Divisions As Bad As Vietnam Era, New Poll Shows, WASH. Post (Oct. 28, 2017), https://www.w ashingtonpost.com/graphics/2017/national/democracy-poll/?utmterm=.e10b0 f2ce43f.

170 The Public, the Political System and American Democracy, PEW RESEARCH CENT. 73 (Apr. 26, 2018), http://assets.pewresearch.org/wp-content/uploads/sites/5/2018/04/26140617 14-26-2018-Democracy-release.pdf ("A wide majority of Americans continue to believe that there should be limits on the amount of money political candidates can spend on campaigns: Roughly three-quarters $(77 \%)$ feel that such limits are appropriate. A somewhat smaller 
problem, such as, providing federal candidates with free broadcast time, public financing, and limits on campaign expenditures. ${ }^{171}$ For example, reforms could address one of the primary drivers of campaign costs - the expensive nature of thirty-second broadcast advertisements. ${ }^{172}$ If this is the real issue, then providing some free advertisements for federal candidates on broadcast TV and radio could help alleviate the pressure associated with raising funds to pay for such advertisements. ${ }^{173}$

Another way to look at the problem is that American elections are privately financed, thus privileging those who are successful at shaking the money tree. If this is the ultimate problem, then public financing for elections is the solution. ${ }^{174}$ Public financing has been tried in many different ways across the country from full public financing for candidates in Connecticut, ${ }^{175}$ to partial public financing in New York

majority $(65 \%)$ think that new campaign finance laws could be effective in limiting the amount of money in political campaigns.”).

171 Kathleen M. Sullivan, Political Money and Freedom of Speech, 30 U.C. DAVIS L. REV. 663, 669 (1997) (describing reform proposal which uses public funds/benefits to incentivize candidates to voluntarily limit their spending); Christopher M. Straw, The Role of Electoral Accountability in the Madisonian Machine, 11 N.Y.U. J. LEGIS. \& PUB. POL'Y 321, 360 (20072008) ("One solution ... is increasing the level of campaign subsidies provided by the government.").

172 Arthur N. Eisenberg, Buckley, Rupert Murdoch, and the Pursuit of Equality in the Conduct of Elections, 1996 ANN. SURV. AM. L. 451, 463 (1996) ("[S]ome campaign reforms are, nonetheless, possible. Such reform efforts rather than focusing on spending limits should look to a variety of other mechanisms including public financing, free television time, and franking privileges for all candidates. The best way to reduce the undesirable influence of money is to reduce the financial dependency of candidates."); see also Jeffrey A. Levinson, Note, An Informed Electorate: Requiring Broadcasters to Provide Free Airtime to Candidates for Public Office, 72 B.U. L. REV. 143, 143 (1992) ("Television and radio reach millions of Americans, and requiring radio and television broadcasters to provide free airtime to candidates for public office would best promote Jefferson's idea of ensuring that Americans are informed and, in his view, free. Free airtime would enhance citizen awareness of public issues, encourage participation in our democratic system of governance, and thereby rebuild Americans' sense of community and shared future.").

173 Jørgen Albæk Jensen, Freedom of Speech and the Legal Regulation of Political Campaigns in the United States, 2 Eur. PuB. L. 293, 321-22 (1996) ("A possibility that seems absolutely obvious to a European, but that has never been used in the United States, is to grant free airtime (or airtime at reduced costs) to the candidates either to be used as the candidates want to use it, or combined with certain demands related to the use of free airtime.").

174 Richard Briffault, The Future of Public Funding, 49 Willamette L. REV. 521, 538 (2012-2013) ("In a flat grant system, the larger the initial public grant, the less the need for and the less the dependence on private donations."); see also Joel M. Gora, Free Speech, Fair Elections, and Campaign Finance Laws: Can They Co-exist?, 56 How. L.J. 763, 798 (2013) ("The public funding should be generous and equally available to all qualified candidates, not just to those representing the two major parties.").

175 J. Mijin Cha \& Miles Rapoport, Fresh Start: The Impact of Public Campaign Financing in Connecticut, Demos (Apr. 2013), http://www.demos.org/sites/default/files /publications/FreshStart_PublicFinancingCT_0.pdf. 
City, ${ }^{176}$ to vouchers in Seattle. ${ }^{177}$ And, of course, for decades there was presidential public financing that combined partial public financing in the primary with full public financing in the general election. ${ }^{178}$ But the presidential public financing system atrophied as the money it offered failed to keep pace with the cost of privately funded presidential runs. Congress has never had a public financing system, though there have been a number of legislative proposals to provide public financing to Congressional candidates. ${ }^{179}$ A properly designed public financing system would give federal candidates an alternative to endless call time.

Alternatively, if the problem is that candidates waste their precious time that they should be legislating, one solution suggested by Professor Jerry $\mathrm{H}$. Goldfeder is candidates could be banned from making personal solicitations of campaign funds. The U.S. Supreme Court upheld this type of personal solicitation ban for judicial candidates in Williams-Yulee v. Florida Bar in 2015. ${ }^{180}$ And as Professor Goldfeder notes this idea is not so outlandish as for one hundred years in New York, "[p]olice who run for office are also barred from soliciting or receiving contributions ...." "181 This approach would at least get elected officials out of the fundraising cubical and back to the work of legislating.

176 Spencer Overton, Matching Political Contributions, 96 MinN. L. REv. 1694, 1696 (2012) ("Multiple matching funds address the core challenge to financial political participation-a lack of income."); see id. at 1714 ("Multiple matching programs increase participation, as demonstrated by the New York City program that matches the first $\$ 175$ of a political contribution at a six-to-one ratio."); see also Michael Waldman, Political Accountability, Campaign Finance, and Regulatory Reform, 18 N.C. BANKING INST. 83, 88 (2013) (advocating for increasing small donor contributions by having a public match on those funds because it changes the mix of those who contribute to political campaigns).

177 Lawrence Norden \& Douglas Keith, Small Donor Tax Credits: A New Model, BRENNAN CENT. FOR JUST. 2 (2017) ("In the last two years, voters in Seattle approved a program which allows residents to make small political donations using tax dollars, and voters in Tallahassee passed a program that refunds small donations."). And in late breaking news the District of Columbia adopted public financing for city candidates. See Peter Jamison, D.C. Mayor, Reversing Course, Signs Law Creating Publicly Financed Campaigns, Wash. Post (Mar. 13, 2018), https://www.washingtonpost.com/local/dc-politics/dc-mayor-reversingcourse-signs-law-creating-publicly-financed-campaigns/2018/03/13/699b6e90-26f5-11e8-b

79d-f3d931db7f68_story.html?noredirect=on\&utm_term=.aa5f06e.

178 Ciara Torres-Spelliscy, How Much Is an Ambassadorship? And the Tale of How Watergate Led to a Strong Foreign Corrupt Practices Act and a Weak Federal Election Campaign Act, 16 CHAP. L. Rev. 71, 71 (2012).

179 John P. Sarbanes \& Raymond O'Mara III, Power \& Opportunity: Campaign Finance Reform for the 21 st Century, 53 HARV. J. ON LEGIS. 1, 27 (2016) (advocating for "Government By the People Act" which encourages small donors through a 50\% tax credit on donations up to $\$ 100)$.

180 Williams-Yulee v. Fla. Bar, 135 S. Ct. 1656, 1659 (2015).

181 Jerry H. Goldfeder, Ban Candidates From Soliciting Campaign Dough, N.Y.L.J. (Nov. 14, 2017, 2:45 PM), https://www.law.com/newyorklawjournal/sites/newyorklawjourn al/2017/11/14/ban-candidates-from-soliciting-campaign-dough/?slreturn=20180329211217. 
Congressman Jolly introduced such a bill that would have barred direct solicitations by Members called the "Stop Act," but the legislation did not pass. ${ }^{182}$

Finally, if the time suck problem is really an arms race problemwherein Candidate A will not stop fundraising out of fear that their opponent Candidate B will not stop fundraising and vice versa-the solution is to have a statutory limit on expenditures. ${ }^{183}$ This, of course, was held to be unconstitutional in both Buckley and in Randall. But if the Court is really reconsidering preserving candidate time as a compelling state interest, as argued should be the case in this Article, then it should additionally reconsider the holdings in these two cases to allow for expenditure limits in the future.

\section{CONCLUSION}

Long ago, in 1884, the Supreme Court recognized the need to protect our democracy from corruption. As the Court said in Ex parte Yarbrough,

[i]n a republican government like ours, where political power is reposed in representatives of the entire body of the people, chosen at short intervals by popular elections, the temptations to control these elections by violence and by corruption is a constant source of danger.... no lover of his country can shut his eyes to the fear of future danger from both sources. ${ }^{18}$

The risk of corruption continues, as privately funded elections leave elected officials on the fundraising treadmill, just as Justice White foretold in Buckley. This is not healthy for Members of Congress or for effective legislating. However, changing this state of affairs will require the Supreme Court to recognize that there is a problem with lawmakers continually interrupting the work of governing to grovel for campaign money. Furthermore, addressing candidates' time should be considered a compelling state interest worthy of solicitude from the Supreme Court. By interrupting their primary task of lawmaking, fundraising may

182 Editorial Board, This Would Be A Nice First Step On Campaign Finance Reform, WASH. Post (June 10, 2016), https://www.washingtonpost.com/opinions/this-would-be-a-nic ce-first-step-on-campaign-finance-reform/2016/06/10/745de05a-2e69-11e6-b5db-e9bc84a2 c8e4story.html?utm_term=.6b8002603709 (discussing the desirability of the Stop Act); Gov Track, H.R. 4443 (114th): Stop Act, https://www.Govtrack.us/congress/bills/114/

hr4443 (noting that the Stop Act died).

183 Harold E. Ford \& Jason M. Levien, A New Horizon for Campaign Finance Reform, 37 HARV. J. ON LEGIS. 307, 319-20 (2000) (arguing that in a voluntary public financing system, candidates' expenditures must also be limited or they will not be encouraged to join the public financing system); Hasen, supra note 1, at 35 (2014) ("Reformers must demonstrate to the new Court that reasonable limits on corporate, and potentially even individual, spending would not squelch political competition or inhibit robust political debate.").

184 Ex parte Yarbrough, 110 U.S. 651, 666-67 (1884). 
degrade the quality of Members' legislative work. ${ }^{185}$ Thus, the Supreme Court should take the issue of incumbent Members' and sitting Presidents' fundraising more seriously because the constant interruptions impedes and degrades the quality of our representative democracy. ${ }^{186}$

185 See Jim Taylor, Technology: Myth of Multitasking, PsychOL. TODAY (Mar. 30, 2011), https://www.psychologytoday.com/blog/the-power-prime/201103/technology-mythmultitasking (Research on the American Psychological Association's website offers evidence that trying to multitask is not effective or efficient. It takes $40 \%$ more time to try and switch tasks than to focus on a single task).

186 Jett, supra note 116, at 496 (discussing interruptions as intrusions). 